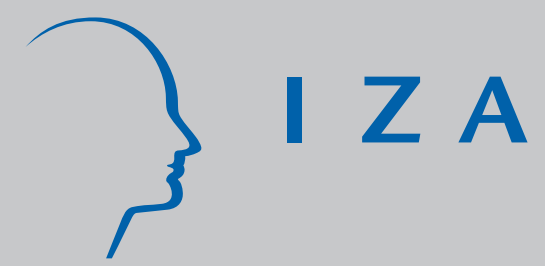

IZA DP No. 8779

Burden or Relief?

Fiscal Impacts of Recent Ukrainian Migration to Poland

Pawet Kaczmarczyk

January 2015

Forschungsinstitut zur Zukunft der Arbeit Institute for the Study of Labor 


\title{
Burden or Relief? \\ Fiscal Impacts of Recent Ukrainian Migration to Poland
}

\author{
Paweł Kaczmarczyk \\ $M P C$, European University Institute, \\ CMR, University of Warsaw and IZA
}

Discussion Paper No. 8779

January 2015

IZA

P.O. Box 7240

53072 Bonn

Germany

Phone: +49-228-3894-0

Fax: +49-228-3894-180

E-mail: iza@iza.org

Any opinions expressed here are those of the author(s) and not those of IZA. Research published in this series may include views on policy, but the institute itself takes no institutional policy positions. The IZA research network is committed to the IZA Guiding Principles of Research Integrity.

The Institute for the Study of Labor (IZA) in Bonn is a local and virtual international research center and a place of communication between science, politics and business. IZA is an independent nonprofit organization supported by Deutsche Post Foundation. The center is associated with the University of Bonn and offers a stimulating research environment through its international network, workshops and conferences, data service, project support, research visits and doctoral program. IZA engages in (i) original and internationally competitive research in all fields of labor economics, (ii) development of policy concepts, and (iii) dissemination of research results and concepts to the interested public.

IZA Discussion Papers often represent preliminary work and are circulated to encourage discussion. Citation of such a paper should account for its provisional character. A revised version may be available directly from the author. 


\section{ABSTRACT \\ Burden or Relief? \\ Fiscal Impacts of Recent Ukrainian Migration to Poland}

Immigration has become recently one of the most important subjects in socio-economic debates. In many countries immigrants are commonly presented as a threat to host economies and societies. On top of this fiscal impacts of immigration are ones of the hottest and most controversial topics in recent debate on migration. Against this background this paper aims at (1) discussing and synthesizing both theoretical and empirical literature on fiscal impacts of immigration, and (2) assessing empirically net fiscal position of Ukrainian immigrants in Poland. On the theoretical level we show that there exists no clear or coherent theoretical framework to explain fiscal effects of migration. Outcomes of empirical studies are mixed and not unequivocal, but generally prove that fiscal impacts of immigration are small or negligible. In terms of explanation, type of migration, labor market incorporation (absorption) and institutional framework at destination (structure of the welfare state) are presented as critical factors. Importance of those factors is clearly supported by empirical analysis presented. Net fiscal position of Ukrainian immigrants in Poland is unequivocally positive (and more beneficial than it is in case of the natives). This is mostly due to favorable characteristics of incoming immigrants (in terms of age and education) and particular migration strategies in work (pure labor migration). These features, however, to a large extent result from modes of labor market incorporation and structural characteristics of the Polish welfare state.

JEL Classification: F22, H55, H61, J11, J61, J68

Keywords: immigration to Poland, Ukrainian migration, welfare impacts of migration, net fiscal position

Corresponding author:

Paweł Kaczmarczyk

Centre of Migration Research

University of Warsaw

Ul.Banacha $2 b$

02-097 Warsaw

Poland

E-mail: p.kaczmarczyk@uw.edu.pl 


\title{
Burden or Relief? Fiscal Impacts of Recent Ukrainian Migration to Poland ${ }^{1}$
}

\author{
Paweł Kaczmarczyk
}

\section{INTRODUCTION - AIMS AND MOTIVATION}

Last decades saw a significant increase in number of international migrants worldwide. Even if the share of migrants in the total population remains relatively stable since early 1960s the global picture of migration is changing (UNDP 2009). Most of today's migrants target well developed economies with 'traditional immigration countries' (Australia, Canada, the United States) and the European Union. Particularly in those countries/regions immigration is often presented (and perceived) as a threat to host economies and societies. Leaving aside social, cultural or religious issues there is an ongoing debate on the impacts of immigration on well-being of domestic populations. This discussion concerns primarily labor market (impact on wages, displacement effects, risk of unemployment) and fiscal effects of immigration.

The latter subject became one of the most controversial topics in recent migration debates. Immigrants are commonly blamed for burdening state and local budgets of host countries and impacting negatively the welfare of non-migrants. This discussion (and its temperature) is perfectly understandable when considering the very nature of both migration and welfare system. While analyzing the fiscal implications of immigration Freeman (1986) emphasizes the very logic of the national welfare systems which - by their nature - were developed as closed systems. The idea of membership which is crucial for systems of distribution implies the existence of non-members, agents excluded from the process of sharing ${ }^{2}$. Thus the main challenge to the welfare system results from the very fact that national welfare states do exist in a global economy and become increasingly dependent on other players in the global economy. In other words, the openness of the welfare state is supposed to create extraordinary challenges to its viability and sustainability. International trade and capital flows have indirect or direct impact on the welfare system. The impact of migration, on the other hand, is direct and critical. According to Freeman (1986) there is an inescapable tension between closed welfare states and free mobility of labor undermining the whole system in the long run. This might be very radical but also an exemplary statement, one of many in recent literature on immigration and welfare.

Against this background an aim of this paper is, first, to review and synthesize existing theoretical and empirical literature on the presence of immigrants in the welfare systems ${ }^{3}$ and their impacts on contributory (taxes paid) and beneficiary (benefits and goods obtained) side of it, and, second, to assess empirically one particular migration process: recent migration from Ukraine to Poland. We

\footnotetext{
${ }^{1}$ The author would like to express his thanks to the members of the Migration Policy Centre (European University Institute) and the Centre of Migration Research (University of Warsaw), particularly to Phillippe Fargues, Alessandra Venturini, Marek Okólski and Joanna Nestorowicz for their comments and suggestions that helped to improve this piece of work significantly. All remaining mistakes are mine. ${ }^{2}$ Moreover, in historical terms the welfare state emerged in a very particular context - the context of the nation state that granted and protected the welfare arrangements. Thus, the system entails limited access to its benefits and this access is usually bounded to citizenship.

${ }^{3}$ Following Nannestad (2007) welfare system will be defined as a system which comprises of income transfers (cash benefits) and in kind benefits (public services including health, education, child care, elderly care etc.). The analysis will refer predominantly to benefits and payments related to participation in the welfare system. Importantly, possible externalities related to presence of immigrants in the host society (labour market impacts, impacts on housing, consumption etc.) will not be considered.
} 
hypothesize that the fiscal impacts of immigration are complex and dynamic and thus a proper assessment demands careful empirical strategy and should refer to both static and dynamic approaches. The analysis presented will be subordinated to following research questions: Is there a theoretical consensus regarding fiscal impacts of migration? What are the most important factors influencing fiscal position of immigrants at destination? Is there a convergence regarding empirical assessment of fiscal impacts of migration?

In empirical terms we will refer to one of the most interesting migration processes in contemporary Europe - immigration of Ukrainians and ask the question what is the net fiscal position of Ukrainian immigrants in Poland. Poland is still lagging seriously behind in its process of transition into net immigration area (see section III). The scale of immigration is relatively low (as for European standards) but it is likely the scale will increase in the future as a result of attractiveness of the EU in general as well as of opportunities created by the Polish economy. The importance of future immigration to Poland should not be underestimated for at least two reasons. First, there are already clear signs of labor market segmentation and growing demand for foreign labor (Duszczyk et al. 2013; Kaczmarczyk 2008). Second, Poland is one of the countries which combine unfavorable demographic dynamics (lowest low fertility) with massive net emigration both leading to rapid population ageing. Third, unstable political situation in Ukraine - the most important sending country - can fuel easily more massive migration flows. As a consequence, more numerous immigration can become an inevitable phenomenon in the future and that creates challenges for the country in general and for social and labor market institutions in particular, including fiscal sphere. Thus, analysis presented in the paper is important because it helps to understand recent and future consequences of the inflow for Poland. Moreover, to our knowledge this is the very first study on welfare impacts of migration to Poland (with only a few on economic impacts of immigration, generally). The paper contributes to the general discussion on immigration and its impacts. This is mostly due to the fact that in case of Poland we can observe specific forms of migration, including temporary or circular mobility in both regular and irregular forms. These forms of migration/mobility are specific but not unique. In contrary, temporary migration schemes are common in many less developed countries, including Central and Eastern Europe. Thus, the case of Ukrainian immigrants in Poland can be used as an exemplary one for European policy makers constantly interested in designing policy schemes involving short-term or seasonal movements.

In terms of theoretical outcomes we show that there exists no clear or coherent theoretical framework to explain fiscal effects of migration. Similarly, outcomes of empirical studies are mixed and not unequivocal. Generally, however, they show that fiscal impacts of immigration are small and the net fiscal position of immigrants is to be explained in terms of socio-demographic characteristics, type of migration, labor market incorporation (absorption) and institutional framework at destination (structure of the welfare state and the labor market). In terms of empirical outcomes, presented results show that Ukrainian immigrants in Poland are unambiguously net fiscal contributors. Moreover they held this position to a larger extent than it is in the case of the native population. All scenarios considered (differing with respect to assumptions taken) provide similar results (with only small differences resulting from inclusion/exclusion of dependents and elderly). The general assessment of fiscal position of Ukrainian immigrants in Poland is positive mostly due to favorable characteristics of incoming immigrants (in terms of age and education) and particular migration strategies in work (pure labor migration). These features, however, to a large extent result from modes of labor market incorporation and structural characteristics of the Polish welfare state. 
Structure of the paper is following. Next section presents a review of both theoretical and empirical literature on the fiscal impacts of migration. Section III summarizes available data on Ukrainian immigrants in Poland to provide a broad understanding of the phenomenon under consideration. Fourth section discusses data used and empirical strategy applied. Results obtained are presented and discussed in the fifth section aiming at assessment of fiscal position of recent immigrants in Poland. Last section concludes.

\section{FISCAL IMPACTS OF MIGRATION - THEORETICAL AND EMPIRICAL LITERATURE}

In this paper we follow typology of approaches to migration and welfare systems proposed by Nannestad (2007) who suggests to focus on four main issues while analyzing mutual relationships between immigration and the welfare systems: 1 ) the role of welfare systems as potential pull factors (welfare magnets hypothesis); 2) impacts of welfare systems on immigrants' behavior at destination, i.e. a question to what extent the architecture and rules of the welfare system act as factors creating incentives and disincentives for successful immigrant integration; 3) impacts of immigration on the welfare system at destination, i.e. distributional and fiscal impacts of immigration; 4) impacts of immigration on the future of welfare systems, i.e. analysis in which welfare systems are treated endogenously (political economics of migration). This list can be extended by adding 5) relationships between immigration and the welfare system as a base for assessment (and creation) of migration policies. Due to the very nature of the empirical analysis presented in the fifth section we will focus almost exclusively on point 3), with only minor reference to points 1) and 5).

While analyzing the literature devoted to the welfare impacts of migration one needs to distinguish between studies looking at the welfare in general terms (impacts on the social welfare) and those assessing fiscal impacts of migration (impacts on the welfare state). We will focus predominantly on the latter, but the former is worth noting due to the fact that it influences significantly economic perception of immigration and, to some extent, literature on fiscal impacts of immigration. Most of the papers start from neo-classical economic literature on trade and mobility of factors of production seeing migration as beneficial to the nationals of the host country and detrimental for those inhabitants of the source country who are not mobile (this is why this strand of literature is often referred to as neoclassical trade literature). Starting from a seminal paper by Berry and Soligo (1969) many authors present more or less sophisticated models to assess the welfare impacts of immigration (Wong 1985; Djajic 1997, 2009; Fuest and Thum 1999; Michael 2003; Djajic and Michael 2009). Unfortunately, part of above quoted models suffers (in terms of welfare assessment) from rather simplified understanding / defining of welfare and welfare function and denying impact of migrants' remittances and fiscal policies. Fiscal policies have been introduced to the modeling exercise by Michael and Hatzipanayoutou (2000, 2005), and Michael (2011) who refer (and develop) a model including taxation (both direct and indirect), income transfers and public goods. Outcomes of theoretical considerations quoted above should be treated with caution for a number of reasons. First, outcomes are very sensitive to assumptions taken (in fact they play decisive role in assessment of the welfare impacts of migration). Second, part of the assumptions is detached from socioeconomic reality. The most critical point refers to low skilled migrants who are commonly assumed 
to be net beneficiaries. It is also assumed that migration policies are efficient in that sense that they can impact both size and structure of incoming flows.

The second strand of literature departures from the purely welfare oriented approach and focuses more on impacts of immigration in presence of redistributive policies. Thus fiscal impacts of immigration are addressed theoretically in a direct or an indirect way. Most of the models start from the classical $\mathrm{H}-\mathrm{O}$ framework and then focus on the impact of migration on redistributive policies available. From the models presented by Wildasin (1994) and Wellisch and Wildasin (1996) it follows that, first, countries may wish to attract fiscal contributors and to discourage fiscal beneficiaries, and second, welfare impacts of immigration are strictly conditional on the net fiscal position of immigrants which is to be modeled in a different way (see Storesletten 2000, 2002; Chand and Paldam 2004). Importantly, Wellisch and Wildasin (1996) explicitly state that the measuring of the net fiscal contribution of immigrants is critical for evaluation of immigration (and redistribution) policies. This status tends to change over the life cycle (due to changes in consumption patterns, savings, labor market performance, health status and also factors related to migration: return migration, remittances etc.) and is also related to demographic structure of newcomers. Additionally, proper assessment should go beyond the static analyses: immigrants may change their status, they can settle and be joined by families etc. Thus they suggest interpreting the critical variable $z_{i}$ (net fiscal contribution of immigrants) as the present value assessed over the entire horizon of one's life (eventually including fiscal position of one's descendants). Wellisch and Walz (1998) emphasize the clear preference observed around the globe to prefer free trade over free migration (e.g. most of free trade areas are reluctant to open borders for a free movement of labor). According to the authors a possible explanation for this "paradox" lies in the presence of redistributive policies and their linkages to immigration, i.e. the existence of the modern welfare state is one of the main factors hindering free mobility ${ }^{4}$.

As compared with models dealing with the welfare as pull factor or political economics of immigration, theoretical considerations related directly to fiscal impacts of migration are very scarce. One of the commonly quoted is the one proposed by Boeri (2010) who applies a simple static model of migration to quantify the impact of immigration on the welfare of native population. The main aim is to identify the major channels by which immigration can affect both the generosity and the desirability of redistributive policies.

The model distinguishes two types of workers whose welfare functions are given by:

$$
W^{s}=w_{s}(1-t)
$$

for skilled workers ${ }^{5}$ and

$$
W^{u}=w_{u}(1-t)\left(1-u_{u}\right)+u_{u} b
$$

for unskilled ones. In both formulas $w_{i}$ denote wages, $u_{i}$ unemployment rate specific for particular skill level, $b$ the level of benefits, and $t$ the proportional tax rate paying the unemployment benefits

\footnotetext{
${ }^{4}$ It is necessary to note that there are other explanations possible, e.g. due to certain factors (market structure, differences in technologies, tradable and non-tradable goods) price equalization is unlikely, and immigration may affect native workers in many ways. Moreover, according to the Ricardian trade model or the new economic geography immigration and trade are complements and not substitutes (Wong 1995; Krugman 1991).

${ }^{5}$ Model assumes that there is no unemployment among high skilled workers. Thus in their case taxes are to be treated as a pure transfer to unskilled workers.
} 
(assumed to be the only redistributive transfer in this economy). Further, number of immigrants related to the receiving population is denoted by $m$ and the share of unskilled workers among natives $\gamma$ and among immigrants $\gamma_{m}$ (in both cases holds $0<\gamma<1$ ). Unemployment rates are assumed to reflect only differences in the skill composition of both immigrants and native workers.

Level of benefits is assumed to clear the government budget (for any given tax rate) and is given by:

$$
b=t \frac{w_{s}\left[(1-\gamma)+m\left(1-\gamma_{m}\right)\right]+w_{u}\left[(1-u)\left(\gamma+\gamma_{m} m\right)\right]}{u\left(\gamma+\gamma_{m} m\right)+\phi m}
$$

Where $\phi$ denotes the "residual dependency" term capturing extreme levels of transfers usage by migrants $\left(-\gamma_{m}<\phi<\left(1-\gamma_{m}\right)^{6}\right.$. Then the impact of immigration on the welfare of natives can be expressed as follows:

$$
\frac{d W}{d m}=u \gamma \frac{d b}{d m}-\left(w_{s}(1-\gamma)+w_{u} \gamma(1-u)\right) \frac{d t}{d m}
$$

If yes, the effect of immigration on the welfare of natives is determined only by the way transfers and taxes do react in case of the inflow (Boeri refers to those effects as to benefit and fiscal externalities). In such a framework it is possible to show that the benefit externality $\frac{d b}{d m}$ will depend on the net fiscal position of immigrants (i.e. whether taxes paid are higher than benefits received) and that the presence of migrants can lead to decrease in $b$ (level of benefits). Obviously, under set of assumptions taken this will refer to unskilled natives only (they are the only ones at risk of unemployment). Moreover, when the net fiscal position of immigrants is negative and the government attempts to keep the level of benefits as constant, the necessary increase in social spending is to be matched by higher taxation (fiscal externality: $\frac{d t}{d m}$ ). Due to the fact that the tax base is larger than "benefit base" (due to assumptions taken) the fiscal externality will be spread over larger population and thus not that significant as in the previously analyzed case.

Generally, in the Boeri model (2010) there are two variables crucial for the determination of welfare impacts of immigration (see (3) and (4)) - share of unskilled workers among immigrants $\left(\gamma_{m}\right)$ and the residual dependency term $(\phi)$. If yes, the model can be easily extended by referring to Borjas (1987, $1994,1999)$ model of migrants' self-selection. In such a case (i.e. when skill level of immigrants is treated endogenously) any increase in taxation in the host country will affect negatively the skill composition of newcomers and thus deepen effects suggested above. In such a case, migration may impact negatively the welfare of natives even if the net fiscal position of migrants is positive ${ }^{7}$. Nonetheless, the net fiscal position of immigrants remains the key factor in the analysis because it does affect not only the short-term outcomes of the inflow but also long-term impacts related to (possible) changes in the immigrants' skill structure.

Similarly to above discussed models on social welfare, those models assessing fiscal impacts of immigration suffer from applying very strict and not necessarily realistic assumptions. Those assumptions are important for the sake of building a relatively simple economic model but, in fact, very often they are seriously detached from socio-economic reality. The process of socio-economic integration of immigrants is a complex one and such is also the assessment of their fiscal impacts

\footnotetext{
${ }^{6}$ When it is negative it indicates the low take-up of transfers or abuse of it when it is positive.

${ }^{7}$ Again, this is mainly due to particular set of assumptions taken (e.g. risk of unemployment, welfare regime).
} 
(see Figure 2). Even if there is no solid or robust theoretical basis for assessment of immigration impacts on the welfare state, there are several attempts to provide at least a theoretically well founded framework of analysis.

First, this type of analysis can be extended while assessing the institutional framework at destination. Chand and Paldam (2004) provide an interesting exercise while suggesting assessing the impacts of immigration in case of three stylized types of societies: a guest worker society ("Dubai type"), an immigrant society ("US type"), and a tax-based welfare state ("Nordic type"). In that way it is possible to assess the effects of inflow in relation to the institutions of receiving economy crucial as emphasised by Wildasin (1994), Wellish and Wildasin (1996) and DeVoretz (2006). The analytical framework employed is relatively simple but still very useful for the sake of empirical analysis and, at the same time, it addresses at least some of the problems noted above (see Wildasin 1994).

Authors apply the overlapping generations framework and look at an immigrant (outsider) entering (legally) the well-developed country in $t=0$ and then establishing a family and living forever through succeeding generations. Instead of using the term integration (not precise in labor market terms) authors refer to the labor market absorption, i.e. an immigrant is fully absorbed when he receives the salary $w_{D C}$ (the same as insiders; as compared to $w_{L D C}$ ), he has the same unemployment rate and receives the same welfare benefits. If yes, difference between $w_{D C}$ and $\lambda_{D C}$ measures the development of the absorption process, Figure 1. It is assumed that directly upon arrival the immigrant is unemployed $(w=0)$, then starts working with salary rising over time - this process is depicted by a labor absorption function $\lambda_{D C}$ rising from 0 to 1 . When $\lambda_{D C}<\lambda(x)$ there is an excess subsidy paid to the immigrant (depending on time spent in a given country and welfare state institutions $-\rho(t, \ldots))$. Additionally, authors introduce a ratio of surplus production of immigrants $z$ (with a benchmark set as $z=0.25$ ). Last but not least, $X$ denotes the time of social break even, i.e. time when the excess subsidy equals zero (this is intersection of $\lambda$ and $\rho$ curves). The standard model can be presented in a following way, Figure 1 :

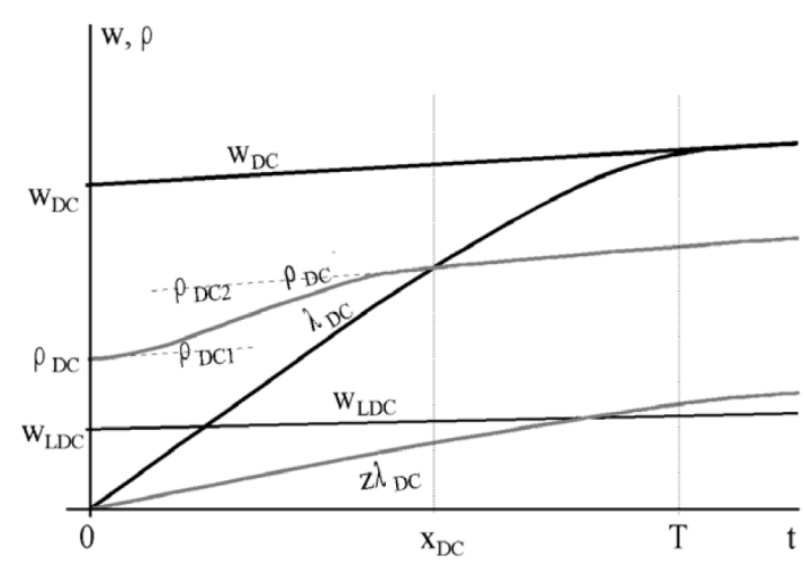

Figure 1. Process of immigrants' absorption - standard case

Source: Chand and Paldam 2004: 7.

As shown above, the wage to be paid at destination is much higher than at origin, however it takes time to reach it $(T)$. The subsidy $\rho_{D C}$ consists of two parts - subsistence payment paid at the level of 
$\rho_{D C 1}$ and the insurance part paid until reaching $\rho_{D C 2} ; x_{D C}$ denotes the break-even point, i.e. time when the immigrant ceases to be the net beneficiary of the host country. Clearly, the shape of the $\lambda$ curve (describing the absorption process) can be modeled in an empirical way because it reflects factors related to particular economy. Chand and Paldam (2004) suggest considering two factors shaping the process of immigrants' absorption: 1) the selection process and 2) the incentives offered by the institutional framework in a given country. Regarding the first case they argue that the immigrants of diverse "labor market values" will be absorbed in a different way. In a simple words, the immigrants with a high labor market value (not necessarily highly skilled!) will try do get to those countries where there are best chances to be absorbed fully and quickly. On the other hand, the immigrants with a low labour market value will rather prefer countries with generous social support (and not necessarily offering clear path towards full absorption). ${ }^{8}$ The shape of the $\rho$ curve is determined by the organization of social security in the host country. Particularly, it will depend on the extent of the social welfare, value of social benefits, extent of insurance based system, etc. Further the shape of both curves resulting from welfare and labor market institutions impacts dramatically the welfare impacts of immigration. Additionally, the structural framework at destination creates particular incentives for the immigrants themselves to integrate or not to integrate (and, as authors argue, in practice the incentive effect and the adverse selection effect are hardly distinguishable and will reinforce each other) ${ }^{9}$.

Second, importance of the dynamic approach is critical. Storesletten (2000) points that the typical sequence of welfare effects related to the presence of particular immigrant is following: short period of net costs directly after arrival (i.e. prior to employment), long period of tax revenues and retirement with related net benefits. Additionally, proper analysis should encompass more than only one generation (and include at least offspring of recent generation). In such a framework, immigration (admission of foreigner) can be viewed as a public investment (Storesletten 2002 - see also seminal papers by Simon $(1984,1989)$ and DeVoretz $(2006))$. Storesletten $(2000,2002)$ does not attempt to provide a welfare analysis but a "dynamic accounting exercise of government revenues and expenditures" (Storesletten 2002:2) and tests whether change in immigration policy could resolve the fiscal problems faced by the US and Sweden. In methodological terms he refers to a general equilibrium overlapping generations model. Thus, Storesletten explicitly applies the dynamic approach and uses the net present value of getting (admitting) one extra migrant as main indicator. The analysis of immigrants includes their main socio-demographic characteristics as well as age at the time of immigration and their legal status. In case of this particular model only the first-order effects of immigration are captured, i.e. effects related to particular cohort of immigrants since their admission to retirement (with respective costs and benefits). Additionally, Storesletten (2002) introduces a break-even analysis defined in terms of expected employment rates of immigrants necessary to keep the positive net fiscal contribution ${ }^{10}$.

\footnotetext{
${ }^{8}$ This approach can be easily extended by referring to the model of the immigration market presented by Borjas (1999).

${ }^{9}$ Chand and Paldam (2004) introduce also different outcomes for two types of competition between immigrants and natives. Under certain conditions immigrants may displace natives (e.g. when they are keener to work and accepted harsh working conditions, they are more enterprising or they are differences in social security provision) which may lead to social tensions. This perspective seems too simplistic. Particularly, as shown by Piore (1980) and other there are motivational issues which are responsible for the segmented labor structures present in most well developed countries.

${ }^{10}$ The break-even rate is defined as the participation rate such as the NPV for a newly admitted immigrant equals 0.
} 
To sum up, Figure 2 shows - in a schematic way - the set of factors (potentially) influencing the fiscal position of immigrants and their contribution to public treasury and answers two of research questions asked in the introduction and related to theoretical considerations on fiscal impacts of immigration.

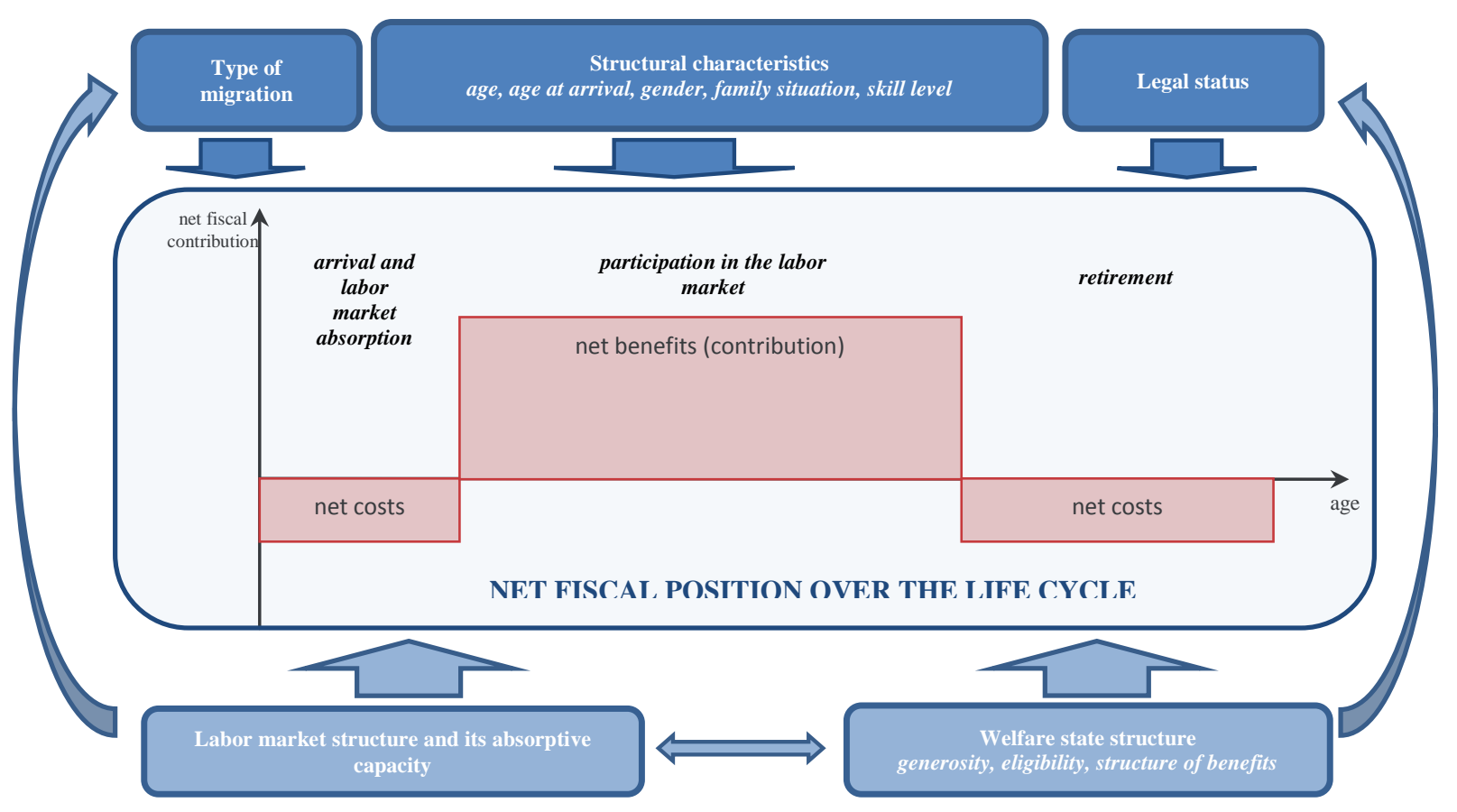

Figure 2. Factors influencing net fiscal position of immigrants

\section{Source: Own elaboration.}

From the theoretical review presented above (as well as from the empirical review to follow) the critical subject of interest for empirically oriented researchers is the net fiscal position of immigrants (in static or dynamic terms). The net fiscal outcome of presence of immigrants in well developed countries is not only attributable to structural characteristics of immigrants or type of migration but also to structural conditions in the host country, particularly characteristics of its labor market and welfare state organization. Moreover, those structural features are expected to shape both scale and structure of immigrant flows via direct incentives or selection process (e.g. according to the welfare magnet hypothesis) (see also Kaczmarczyk 2013; Kaczmarczyk and Rapoport 2014).

Empirical studies assessing net fiscal impacts of immigration can be divided into two broad categories - static studies and dynamic studies ${ }^{11}$. The former approach refers to a given year (tax year) and compares the contribution of immigrants to the public treasure (in form of direct and indirect taxes; in practice, most studies are limited to the first case) with the value of benefits and services received. The latter attempts to compute the net present value of both contributions and benefits obtained over the lifetime of migrants (and their children, if necessary). Both approaches have their advantages and disadvantages. The static approaches are relatively simple to apply, use historical data and neither demand detailed data on generations nor strict assumptions concerning

\footnotetext{
${ }^{11}$ OECD (2013) distinguishes between three types of studies: static accounting (cash-flow) models, dynamic modelling and macroeconomic models. Due to the fact that the second and third category refer to dynamic accounting we present them as a joint category.
} 
future events (concerning immigrants and the native-born as well as the government's policies). However, they lack forward-looking perspective (critical for policy oriented assessments), assessment of long-term consequences of recent migration processes (e.g. inflow of persons at mobile age) and proper assessment of population ageing and its dynamics. On the other hand, dynamic approaches can provide a forward-looking perspective with a possibility to assess the fiscal impacts of immigration in the life-cycle framework and offer an option to assess the impact of immigration on structural changes resulted from population ageing (e.g. pension system and its sustainability). This all, however, at expense of very strong assumptions concerning the future: those assumptions include variables related to immigrants (fertility rates, life expectancies, return migration rates, productivity rates, labor market participation rates, regularity rates etc.), to natives (similar set of assumptions) and to the government (tax rates, government spending, structure and characteristics of the pension system). From the empirical evidence it follows that outcomes of the dynamic approaches tend to depend strongly on the set of assumptions made (Storesletten 2000, 2002; Collado et al. 2003).

First studies on fiscal position of immigrants have been proposed with reference to "traditional immigration countries". In a pioneer study on the fiscal and welfare impacts of immigration to the United States Simon (1984) refers to the life cycle framework and within a static approach shows that the contribution of immigrants to public coffers is to be assessed as positive (but with significant differences depending on time spent in the US). Akbari (1989) applies a similar approach to assess the net benefits (costs) of immigrants living in Canada and concludes that immigrants who resided in Canada for up to 35 years are benefitting the native population in a clear way. Borjas and Trejo (1991) analyze the participation of immigrants in the US welfare system between 1970 and 1980 and find significant differences in benefits' consumption between cohorts analyzed (attributable mainly to the change in ethnic mix of the immigrants). This way of reasoning is further explored in Borjas and Trejo (1993) looking at differences in welfare use by the country of origin (and its characteristics) and showing that the structural characteristics (including GNP per capita, income inequality, distance to the US and share of forced migrants) that can be attributed to the country of origin explain around $2 / 3$ of the variance in the dependent variable (welfare use rate). Borjas and Hilton (1996) test the participation of immigrants in various programs making the welfare system in the United States and conclude that in case of cash benefits the difference between immigrants and natives (households) is negligible but it gets much wider after inclusion of other programs (meanstested ones, including Medicaid, vouchers or housing subsidies). In the study by Lee and Miller (2000) the subject of assessment is an effect of a change in immigration policy - increase in the number of immigrants by 100 thousand annually (and assuming that the composition will remain unchanged). It turns to be rather small but positive - it amounts to 0.4 percent of the total tax revenue (with the impact on federal treasury being positive since very beginning and the impact on local and state treasury remaining negative, but smaller than the first effect mentioned). Auerbach and Oreopoulos (1999) depart from a critics of traditional studies applied to assess the fiscal impacts of immigration mostly based on static, cross-section approach (e.g. Smith and Edmonston 1997) and apply a dynamic model to assess the economic effects of an immigration policy resulting in halting all further immigration to the United States (after 2000). They find that even a massive change in the immigration policy is expected to have only small effect on the fiscal situation in the US. Moreover, strength of this effect would depend on the fiscal policy itself, i.e. the extent to which existing fiscal 
imbalance will be divided between recent and future generations. ${ }^{12}$ Storesletten (2000) applies the NPV approach and finds that one feasible policy targeting fiscal problems resulting from the population ageing would be admitting 1.6 million of immigrants annually ( 0.62 percent of the population). Additionally, to reach the assumed goals those migrants should be highly skilled and between 40 and 44 years old $^{13}$. Thus he concludes that selective immigration policies are able to remove the need for fiscal reforms. One of the commonly quoted outcomes of Storesletten's study is clear dependence between net fiscal position of immigrants and their level of education but this is mostly due to high sensitivity of results with respect to the income level of immigrants which is strongly dependent on skill level (but this is not to be treated as a general feature).

In the American context there is a long-standing debate on the aggregate fiscal impact of immigration and it seems exemplary in terms of general assessment of immigration. Huddle (1993) assesses the net (annual) fiscal impacts of immigration at USD -40 billion (-0.4 percent of the GDP). This outcome was critically commented by Borjas (1994) because it was based on too simplistic assumptions, including flat rate of taxation (only 7 percent) and displacement effect (every sixth immigrant was supposed to displace a native worker who in turn joined the welfare program). As a comment or response to the study by Huddle, Passel and Clark (1994) estimate the net fiscal surplus of immigration at USD 27 billion ( 0.4 percent of the GDP) with USD 70 billion being paid in taxes and USD 43 billion value of welfare programs and public goods being provided. The problem is however that they assumed that the marginal costs of providing welfare programs to immigrants equal zero. Back-of-the-envelope calculations presented by Borjas (1994) provide the net deficit of the presence of immigrants in the United States at USD 16 billion ( -0.2 per cent of the GDP) (but the results were highly sensitive to assumptions made). Lee and Miller (1998) assess the overall fiscal impact at USD 23 billion ( 0.35 percent of the GDP), but with an assumptions that costs of public goods are not allocated to the immigrants (national defense, R \& D, etc.). Griswold (2012) presents overview of the more recent studies assessing fiscal impacts of the immigration in case of the US. Particularly, he refers to Smith and Edmonston study (1997) showing that immigrants and their descendants create a net fiscal gain for the US economy (80,000 USD in terms of NPV). In case of highly skilled immigrants this gain may become very high $(198,000$ USD). Similarly to previous studies potential uneven impact on different levels of government is emphasised (with federal government gaining the most and state and local governments taking most of the costs related to presence of immigrants).

In the cross-country perspective emphasis is being put on the participation of immigrants in the welfare system. Brücker et al. (2002) depart from the classical economic model showing that more generous welfare systems are expected to attract migrants who are more prone to rely on welfare (due to self-selection migrants' characteristics are more elastic to fiscal measures than natives' characteristics). In case of raw data comparison, large differences between EU countries with respect to migrant welfare dependency are found as regard to both the structure of a given welfare system as well as characteristics of immigrants. Nonetheless, there are two clusters of countries easily identifiable: the first group comprises Germany, Greece, Portugal, Spain and the UK and in this

\footnotetext{
${ }^{12}$ Note however that the outcomes of the model are highly sensitive with respect to the set of assumptions taken (e.g. discount rate, growth rate). Generally, authors concluded that the overall fiscal impact of immigration is largely unclear and depends to large extent on the assumptions concerning immigrants' participation in transfers as well as public goods and services.

${ }^{13}$ This result is particularly interesting in the context of existing policies based on the point system approach. Most of them favour persons aged 20-40 (and with particular skills). According to Storesletten the net fiscal gain for those aged 40-49 exceeds NPVs of persons aged 2024. Thus, if the objective of migration policy would be to maximize the public gain from immigration the criteria should be revised.
} 
case the welfare dependency rates are similar for natives and for the non-EU migrants; in case of the second group (Nordic countries, Austria, Belgium, France and the Netherlands) the welfare receipt among immigrants is significantly higher than in case of natives. Those differences are similar irrespective of the type of welfare benefit / services considered. The general conclusion is that in the mid-1990s immigrants residing in most Western European countries generated relatively large although transitory - contributions to the pension system and this contribution could not be fully offset by the dependency on other kind of transfers (e.g. unemployment benefits). Boeri (2010) shows that immigrants are overrepresented when non-contributory transfers are considered. Barrett and Maitre (2011) use the 2007 EU-SILC data to compare immigrant welfare receipt across Europe (in both unadjusted and adjusted way and looking at EU and non-EU adult immigrants). They conclude that there is very little evidence that immigrants are more likely to receive welfare benefits (when considered in an aggregate way). In case of all types of support only in Poland, France, Finland, Sweden and Denmark the ratio of proportion of immigrants in receipt of support to the proportion of natives was slightly higher than one (with Poland as an outlier - due to low reliability of data used). Gaston and Rajaguru (2013) test the impact of immigration on redistributive policies for 25 OECD countries for the years 1980-2008 (dynamic panel data model) against the above presented framework (particularly exposure/insurance effect (those exposed to risk of being unemployed will prefer more generous welfare system) and redistribution/tax effect (persons who perform well in labor market terms will prefer lower taxation and limited welfare benefits)). Contrary to hypotheses drawn from theoretical analyses they argue that increase in migration leads to higher social spending (i.e. redistribution effect is dominated by the exposure effect).

A very broad and comprehensive overview of theories and empirical evidence related to the fiscal impacts of migration was presented recently by OECD (2013). This is by far the most detailed analysis of this issue done on cross-country basis (even if limited to OECD countries only).

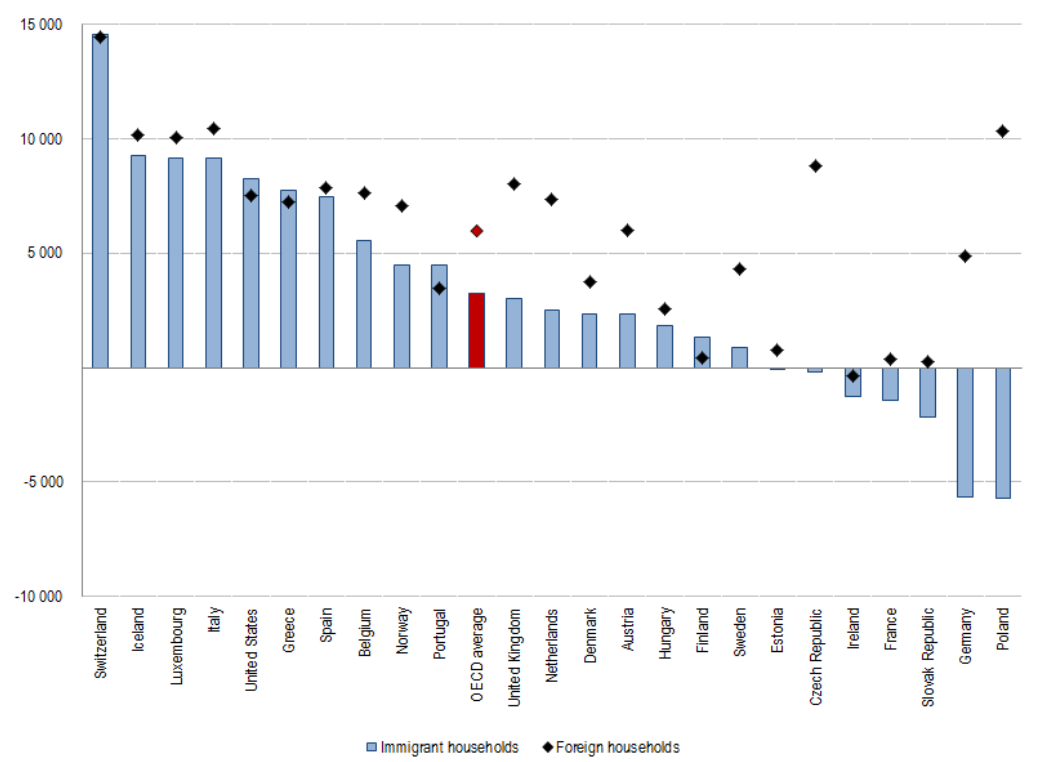

Figure 3. Net fiscal contribution of immigrant (foreign-born) and foreign households, 2007-2009 average (in EUR PPP adjusted)

Source: OECD 2013: 149. 
The net direct fiscal position of immigrants varies between OECD countries but in majority of cases is positive (it holds true not only for traditional immigration countries but also for welfare states as Iceland or Norway), Figure 3. Authors state clearly that even if the estimates of the fiscal position of immigrants can vary, they tend to be small in terms of GDP (impact is rarely larger than 0.5 percent of GDP per year) ${ }^{14}$. Second, generally immigrants tend to have a less favorable net fiscal position than natives but it is not due to higher dependency on welfare but rather due to lower revenues (lower taxation and social security contribution).

Most of the studies quoted show that a large portion of difference in welfare dependency between immigrants and natives disappear when controlling for structural characteristics. However, the answer to the question whether immigrants are net beneficiaries or net contributors to the systems depends not only on such basic characteristics as age, age at arrival or position in the life-cycle (Barrett and Maitre 2011; Brücker et al. 2002; Boeri 2010; Dustmann et al. 2010; OECD 2013) ${ }^{15}$. It also goes beyond the common explanation referring to skill level (with low-skilled workers commonly assumed to be net burden). In many cases the welfare use by immigrants depends on the rules and structural characteristics of the welfare system (e.g. it is country specific). OECD study (2013) points to three important characteristics responsible for different position vis-à-vis state budget: age, education and labor market status. Interestingly, first two characteristics can explain relatively small part of the difference in the net fiscal position, while the labor market status is generally the single most important explanatory factor, Figure 4. This allows Authors to conclude that cross-country differences in terms of welfare impacts of migration are due not only to structural characteristics of immigrants but also due to the design of the tax and welfare system as well as the type of immigration - as suggested by Chand and Paldam (2004) and many others. Generally, those countries with relatively higher shares of labor migrants tend to have far more favorable position in terms of fiscal impacts (see also discussion below).

\footnotetext{
${ }^{14}$ Note also significant differences between immigrant and foreign households. OECD (2013) suggests referring rather to country of birth than citizenship - and this due to significant cross-country differences regarding citizenship legislation. In this case the picture can be biased in case of those countries with large numbers of people born outside recent territories (and not necessarily immigrants). As the best example countries of Eastern Europe can serve with Poland as the most prominent case. Analysis provided by OECD (2013) reveals striking differences in age structures between immigrant (foreign-born) and foreign households showing clearly that the first category encompasses many people born outside the recent territory of Poland (i.e. born before 1945). This explains also clear negative sign of fiscal impact in case of this particular category.

${ }^{15}$ Importantly, Brücker et al. (2002) point to several reasons why differences in the welfare dependency may still arise even if controlling for the structural characteristics (residual welfare dependency). Those reasons include: self-selection (according to the welfare magnet hypothesis), migration-specific effects (e.g. psychological trauma in case of the forced migrants or pure linguistic barriers), discriminatory practices (problems with finding and securing job), network effects (leading to exclusion from the mainstream society but also impacting positively the access to welfare), non-portability of entitlements (legislative issues), and relatively lower wages (important in case of income maintenance programs). Moreover, the residual effect is found to grow where generosity of the welfare system is higher (but there is no clear correlation observable).
} 


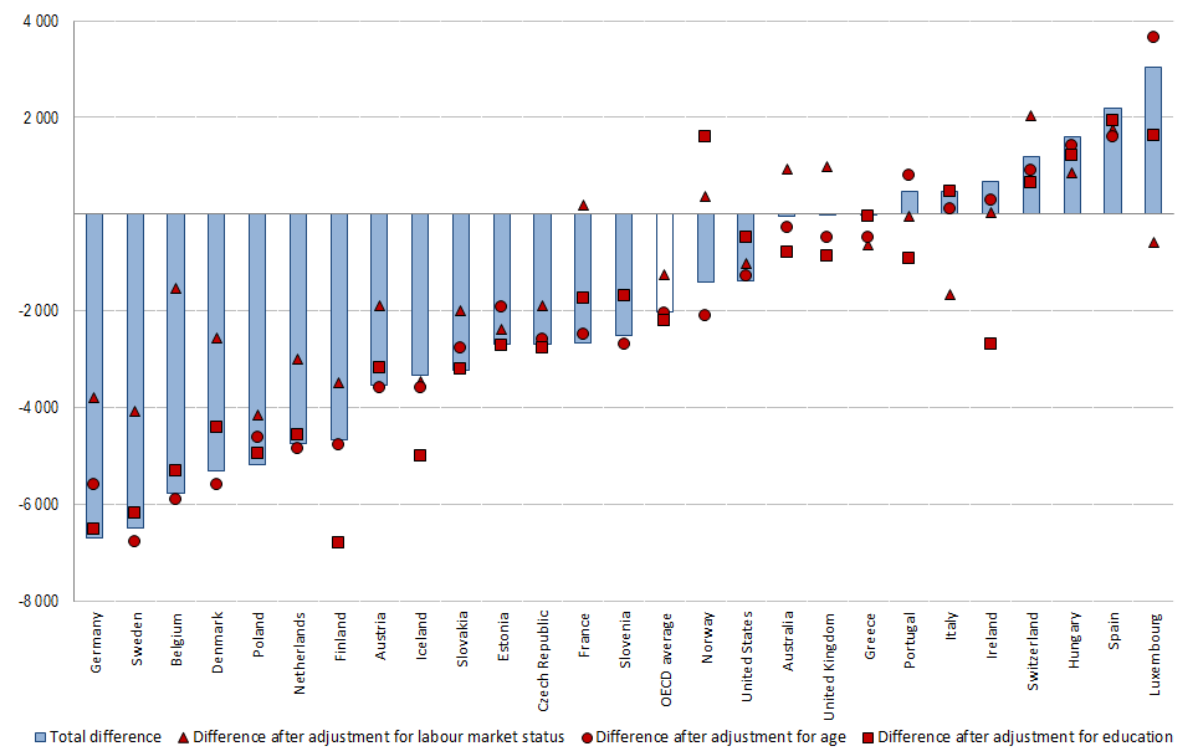

\section{Figure 4. Differences between net fiscal contributions of immigrant and native-born households and their decomposition, 2007-2009 average (in EUR PPP adjusted)}

Source: OECD 2013: 151.

Indeed, European studies on the fiscal position of immigrants prove that the fiscal impact of immigration is strongly system dependent: in countries with more flexible labor markets and relatively less generous welfare systems immigration impacts the welfare system in a positive way (but the scale of its impact is small). Studies on the UK show that the net fiscal contribution of immigrants is positive and potentially sizeable (Gott and Johnston 2002; Sriskandarajah, Cooley and Reed 2005; Rowthorn 2008; Dustmann et al. 2010) ${ }^{16}$. Dustmann et al. (2010) present one of the most interesting studies looking at the impacts of the EU8 (A8 countries) immigration to the UK putting in a fiscal context. In general terms, according to the study A8 immigrants make a positive fiscal contribution to UK public finances over the years 2005-2009 (irrespective of the way that the net fiscal contribution or immigrants were defined) and it was possible mostly due to very high participation rates and employment rates (and despite employment mostly in low skilled and low wage occupations) and relatively higher contribution via indirect taxes. Similar outcomes have been presented for Ireland (Barrett and McCarthy 2008).

On the other hand, outcomes for countries with generous welfare systems are rather negative. In this case however one needs to consider both impacts of the system as such as well as very particular structure of immigration (with large share of refugees or dependents). Wadensjö (2007), Wadensjö and Orrje (2002), Nannestad (2004) and Blume and Verner (2007) consider a fiscal contribution to the Danish treasury in case of two groups of immigrants: persons originated from well developed countries (EU, USA, Australia, Canada) and immigrants from the rest of the world and conclude that while the net contribution is highly positive in the case of the former group, the

\footnotetext{
${ }^{16}$ Note, however, that outcomes provided by Gott and Johnston (2002) were questioned by Coleman and Rowthorn (2004) based on methodology of apportion of costs related to immigration and congestion effects in case of public services.
} 
opposite holds in case of non-Western migrants ${ }^{17}$. Nannestad (2004) concludes that according to the Danish experience unlimited (uncontrolled) immigration creates unresolvable challenges for the Nordic type redistributive welfare regime. The problem lies, however, not necessary in the immigration itself but rather in the construction of the welfare system which is responsible for weak incentives to be economically active and also for creation of entry barriers of immigrants into the labor market through upward pressure on minimum wages. Similarly negative picture is presented for Sweden (Ekberg 1999; Storesletten 2002; Andrén and Andrén 2012). In a commonly quoted articles Hansen and Lofstrom $(2003,2009)$ analyze the welfare position of immigrants and natives in the early 1990s and ask a question whether immigrants do assimilate into or out of welfare. They find that immigrants use welfare to a higher extent than natives. Additionally these differences cannot be explained by observable characteristics only - in case of refugee immigrants - a significant "welfare trap" was found. Authors argue that immigrants - including refugee immigrants are likely to assimilate out of welfare but it is a long term process. Thus, the main factor responsible for increasing welfare utilization of immigrants is the change in structure of incoming migrants (with increasing number of refugee immigrants as the main contributing factor).

Against this background outcomes for Germany are rather mixed. Bird et al. (1999), Castronova et al. (2001) and Riphan et al. (2010) show that immigrants are more likely to receive welfare benefits than native Germans, but their higher welfare participation rates among immigrants are not related to immigrant status itself, but result from their structural characteristics (incomes and household structures). Riphan (2004) finds that out of potential effects on the welfare dependence, the cohort effect was negligible and the same holds true for the country of origin. On the contrary, assimilation effect turns to be significant (and positive in terms of welfare dependency), similarly as the age effect (higher age results in higher probability of welfare dependency). The most important explanatory factors (except of household size and city size) are the labor market status and age at immigration. Brücker et al. 2002 point clearly that in case of Germany most of the welfare dependency is attributable to socio-demographic characteristics of immigrants and not immigration perse.

Importantly, different picture is revealed when analyzing dynamic approaches to welfare impacts of immigration. Several studies point that fiscal contribution of immigrants may be substantial in case of countries suffering (or expecting) rapid demographic decline (but mostly it is presented as transitory effect only). As shown by Bonin et al. (2000), Bonin (2002, 2006); Collado et al. (2004) the size of future changes (higher taxes or lower transfers) depends on the scale of immigration. Bonin $(2002,2006)$ applies the generational account to assess the overall fiscal impact of immigrants coming to Germany and shows that in general terms, immigrants pay less to public coffers but their net position remains positive. The net fiscal position of foreigners residing in Germany remains significantly positive also when accounting for demographic ageing (in a dynamic perspective). Additionally, the net effect of immigration can be even higher when assuming efficient selective migration policy. Slightly different picture provide Chojnicki (2004) and Chojnicki and Ragot (2011) who conclude in case of France that the impact of immigration is difficult to determine but nonetheless small and this is due to the fact that the short term positive impacts are offset in the long term by costs related to ageing of immigrant population. In one of the most interesting papers

\footnotetext{
${ }^{17}$ Similar results are provided by Roodenburg et al. (2003) in the Dutch context. Authors conclude, however, that the negative fiscal contribution of immigrants should not be attributed solely to immigrants and their relatively poor performance but also to the generosity of the Dutch welfare system.
} 
based on Generational Accounting (similarly as in case of Bonin 2002, 2006 and Auerbach and Oreopoulos 2000) Collado et al. (2004) refer to extremely interesting case of Spain who experienced the highest dynamics of the immigration over the last decade. They analyze impact of the inflow against the background of the ageing Spanish society and ask the question whether (such a massive) immigration can improve the fiscal situation of the host country. Results presented show that the impact of immigration on the welfare system is positive and significant, and is supposed to have a significant impact on state budget (scale of this impact depends on the fiscal policy applied). The importance of the dynamic approach to the issue is also stressed by OECD (2013). The study shows clearly that in case of most OECD countries under analysis, the inclusion of pension system contribution (i.e. dynamic accounting exercise) changes significantly the assessment of immigrants' presence in well developed countries and does it in a very positive way. This point is particularly well taken in those countries which already suffer population ageing and at the same time their immigrant populations are significantly younger than native populations (e.g. Southern European countries). Thus, immigration may be treated as a safety valve. Even if this approach can be challenged (see Coleman and Rowthorn 2004) most of the dynamic studies emphasize the positive role of immigration in the sustainability of European welfare systems (see also Kaczmarczyk and Rapoport 2014).

The above presented review of empirical studies does not provide a clear nor coherent picture of fiscal impacts of immigration. Results of most studies presented so far are rather mixed, see Table 1a (in the Annex) ${ }^{18}$. Majority of them conclude that immigrants are using social welfare to a greater extent than natives. Most of those differences, however, disappear when accounting for structural characteristics of immigrants. The answer to the question whether immigrants are net beneficiaries or net contributors to the systems depends not only on such basic characteristics as age, age at arrival or position in the life-cycle. It also goes beyond the common explanation referring to skill level (with low-skilled workers commonly assumed to be net burden). Moreover, the total net fiscal of immigration is strongly system dependent - most of the studies available emphasize the efficiency of labor market incorporation and structure of the welfare system itself. Table 1a shows that in countries with more flexible labor markets and relatively less generous welfare systems immigration impacts the welfare system in a positive way (but the scale of its impact is small). Last but not least, in general terms net fiscal impacts of immigration are small (+/- 1\% of the GDP) and they cannot explain very hot temperature of the public debate on that issue.

\section{UKRAINIAN IMMIGRANTS IN POLAND - QUANTITATIVE AND STRUCTURAL FEATURES}

Poland is one of the traditional emigration countries and (still) a net emigration area. Net emigration is an outcome of two factors: very high intensity of international mobility of Poles and relatively low level of incoming flows. Polish citizens migrate on massive scale since late-19 century. Intensity of these flows increased in the 1980s and then after the EU-enlargement when the relative share of emigrants in the population reached 6-7 percent (Kaczmarczyk 2010). Beginning of transition period saw also increase in scale of immigration to Poland - previously to be considered as (almost) closed country. Poland hosted all possible categories of immigrants: from asylum seekers and refugees, highly skilled expatriates, labor migrants, seasonal workers to family members. Nevertheless, the

18 For a broader discussion of empirical results see Kaczmarczyk 2014. 
scale of immigration is still remarkably low, particularly as compared to the size of out-migration. Recently published data from the 2011 National Census provides a number of 55.4 thousand persons without Polish citizenship staying permanently on the territory of Poland ( 0.1 percent of the total population). The number of temporary migrants (staying in Poland for over 3 months) was assessed at 56.3 thousand. Other sources provide similar numbers. According to the Central Population Register, in the period 2001-2013 around 155 thousand persons previously living abroad registered in Poland for a permanent stay. Number of those registered for temporary stay in 2013 was as high as 81 thousand. Labour Force Survey provides a number of around 60 thousand of foreigners aged 15 years and more staying in Poland in 2013 (Kaczmarczyk et al. 2015). Above quoted data point to specific position of Poland as emigration-immigration country.

Notwithstanding, there are several features of recent immigration to Poland which make this case extremely interesting:

1) Above presented data shows that in Poland the transition from migrant sending to migrant receiving area has not been completed so far. However, according to many observers this seems to be inevitable process. In a sense Poland follows steps of Northern and Western European countries (which changed their position as first) and Southern European countries. According to the concept of migration cycle this transition is closely related to both demographic and economic factors (Okólski 2012). Recent massive emigration seriously hindered the process but there are signs of slow changes with respect to immigration (see below). The scale of immigration, not being large, has become noticeable; moreover, it is likely that the scale will increase in the future as a result of attractiveness of the EU in general as well as of opportunities created by the Polish economy. That creates challenges for the country in general and for social and labor market institutions in particular.

2) Even if "orthodox"-kind, settlement migration to Poland is low or very low, temporary migration is growing in importance. This is the case particularly since 2007 when a new simplified procedure was introduced to allow persons from Eastern Partnership countries to work in Poland without permit for up to 6 months a year. Since then number of documents issued (employers' declarations to intent to employ a foreigner) grew to around 240-250 thousand annually (as compared to around 40 thousand individual work permits issued in 2013). Development of this process highlights a significant potential demand for foreign labor as well as migration pressure from the Eastern Partnership countries (Fihel et al. 2012; Duszczyk et al. 2013; Kaczmarczyk et al. 2015). It also suggests that recent immigration to Poland complies predominantly mobility of labor.

3) In terms of origin, immigrants to Poland come from only a few regions (countries): on the one hand from the post-Soviet space (mainly from Ukraine), on the other, from Vietnam. Recently, number of incoming Chinese or Nepalese migrants started to rise dynamically but it does not change the full picture.

4) In terms of regions of destination, immigrants in Poland are very strongly concentrated, predominantly in large towns and urban areas. Warsaw area is definitely the most important 
one, hosting majority of all immigrants irrespective of their category or country of origin ${ }^{19}$ (Fihel 2007; Górny and Torunczyk-Ruiz 2011).

Against this background we will look now more closely at the Ukrainian immigrants in Poland. Undoubtedly Ukrainians are the single most important immigration group in the country. On more numerous scale this migration started in late 1980s when citizens of post-Soviet states commonly referred to circular migration strategies in order to gain from trade or short-term employment in Poland (Górny et al. 2010). Recently, Ukrainians dominate in most of categories of entry and stay (except for refugees and asylum seekers). In 2011 Ukrainians constituted 24 percent of foreigners identified by the National Census (17 percent in case of those staying temporarily), 28 percent of foreigners registered for temporary stay, 52 percent of working permit holders and, the most importantly in short-term perspective, over 92 percent of persons coming to Poland on the basis of the simplified procedure and these shares remained mostly unchanged since then (based on CSO and Ministry of Labour Data). In structural terms, large majority of Ukrainian immigrants in Poland is working or settled in the Mazowieckie region (Gorny and Torunczyk-Ruiz 2011; Górny et al. 2010; Fihel et al. 2007). This is one the reasons why most of the large scale studies were focused on this particular area. Relatively low number of methodologically acceptable studies is to be attributed to lack of official data (e.g. very low samples of immigrants in data sets like LFS or EU-SILC) and lack of sample frame. Only recently two studies have been completed which referred to the Respondent Driven Sampling as the main method of selection - see next section for methodological details (Górny and Torunczyk-Ruiz 2011; Napierala and Górny 2011). Further we focus on outcomes of one of these studies while discussing structural characteristics of Ukrainian immigrants in Poland (or precisely: in Warsaw area) ${ }^{20}$. Table 1 includes selected characteristics of the sample under consideration (as for 2012).

Table 1. Descriptive statistics of the sample

\begin{tabular}{|c|c|c|c|c|}
\hline \multirow[b]{2}{*}{ Characteristics } & $\begin{array}{l}\text { No. of observation } \\
\text { / Average }+\end{array}$ & $\begin{array}{c}\text { Percentage / Std. } \\
\text { dev. }+\end{array}$ & $\begin{array}{l}\text { No. of observation } \\
\text { / Average }+\end{array}$ & $\begin{array}{c}\text { Percentage / Std. } \\
\text { dev. }+\end{array}$ \\
\hline & \multicolumn{2}{|c|}{ Males } & \multicolumn{2}{|c|}{ Females } \\
\hline \multicolumn{5}{|c|}{ Age } \\
\hline Average age $t$ & 35.01 & 9.907 & 39.56 & 10.992 \\
\hline Persons aged $21-45$ & 145 & 0.784 & 174 & 0.613 \\
\hline Persons aged 46-60 & 32 & 0.173 & 96 & 0.338 \\
\hline Persons aged over 61 & 0 & 0.000 & 4 & 0.014 \\
\hline \multicolumn{5}{|c|}{ Family status } \\
\hline \multicolumn{5}{|l|}{ Marital status } \\
\hline Single & 62 & 0.335 & 70 & 0.246 \\
\hline Informal relationship & 5 & 0.027 & 10 & 0.035 \\
\hline Married & 90 & 0.486 & 106 & 0.373 \\
\hline Divorced/separated & 25 & 0.135 & 71 & 0.250 \\
\hline Widowed & 3 & 0.016 & 27 & 0.095 \\
\hline $\begin{array}{l}\text { Percentage of households with } \\
\text { dependants }\end{array}$ & 13 & 0.070 & 35 & 0.123 \\
\hline
\end{tabular}

\footnotetext{
${ }^{19}$ According to the 2011 National Census over 30 percent of all immigrants in Poland were residing in Mazowieckie region (and particularly in Warsaw area).

${ }^{20}$ Data courtesy of National Bank of Poland and Centre of Migration Research Foundation.
} 


\begin{tabular}{|c|c|c|c|c|}
\hline Level of education & & & & \\
\hline primary & 6 & 0.032 & 10 & 0.035 \\
\hline secondary & 103 & 0.557 & 158 & 0.556 \\
\hline post-secondary and tertiary & 76 & 0.411 & 116 & 0.408 \\
\hline \multicolumn{5}{|c|}{ Migration history } \\
\hline \multicolumn{5}{|l|}{ Year of first migration } \\
\hline before 1990 & 0 & 0.000 & 2 & 0.007 \\
\hline $1990-2003$ & 30 & 0.162 & 87 & 0.306 \\
\hline 2004-2008 & 36 & 0.195 & 66 & 0.232 \\
\hline $2009-2012$ & 119 & 0.643 & 129 & 0.454 \\
\hline Average no. of migrations + & 2.946 & 2.136 & 4.486 & 2.932 \\
\hline \multicolumn{5}{|c|}{ Labour market status } \\
\hline Labour market status - employed & 168 & 0.908 & 270 & 0.951 \\
\hline Labour market status - unemployed & 15 & 0.081 & 12 & 0.042 \\
\hline Wage-employment (last week) & 164 & 0.886 & 260 & 0.915 \\
\hline Average net income & 2762.546 & 1885.493 & 2072.293 & 834.496 \\
\hline Legal status - illegal job + & 38 & 0.250 & 56 & 0.197 \\
\hline \multicolumn{5}{|c|}{ Fiscal position indicators } \\
\hline $\begin{array}{l}\text { Persons claiming payment of taxes } \\
\text { (direct) }\end{array}$ & 78 & 0.476 & 111 & 0.410 \\
\hline \multicolumn{5}{|l|}{ Persons claiming: } \\
\hline Unemployment benefits & 1 & 0.005 & 0 & 0.000 \\
\hline $\begin{array}{l}\text { Family and children-related } \\
\text { allowances }\end{array}$ & 1 & 0.005 & 0 & 0.000 \\
\hline Social assistance payments & 2 & 0.011 & 1 & 0.004 \\
\hline Pension & 0 & 0.000 & 2 & 0.007 \\
\hline Housing allowances & 0 & 0.000 & 1 & 0.004 \\
\hline $\mathbf{N}$ & 185 & 1.000 & 284 & 1.000 \\
\hline
\end{tabular}

Source: Own elaboration based on the RDS/CMR/2012 data base.

From the above presented data it follows that immigrants in the sample are relatively young and this is typical feature of most mobile persons (78 percent of males and 61 percent of females at mobile age). However, the average age is higher than it could be expected and it refers predominantly to women - around 35 percent of females in the sample constitute persons aged over 46 years. This is also clearly visible when analyzing the age distribution of immigrants from Ukraine, Figure 5 . There is an obvious bias towards older age groups in case of women with significant shares of mobile women in their 40s and 50s. This is one of the most prominent features or recent migration from Ukraine to countries like Poland or Italy which job offers is closely related to care sectors. The age distribution is but also function of push factors - poor labor market conditions and family situation of older women. According to the survey data, while in case of men single and married individuals dominate, in case of women around 35 percent constitute divorced and widowed persons. This reflects the specific migration strategy applied by Ukrainian women. Their migration histories are also much longer. In general, majority of migrants in the sample started to migrate to Poland only recently: 85 percent of males and 69 percent of females arrived to Poland for the first time (for non-touristic 
purposes) after the EU-enlargement. However, around 31 percent of female migrants started their mobility paths before $2003^{21}$.

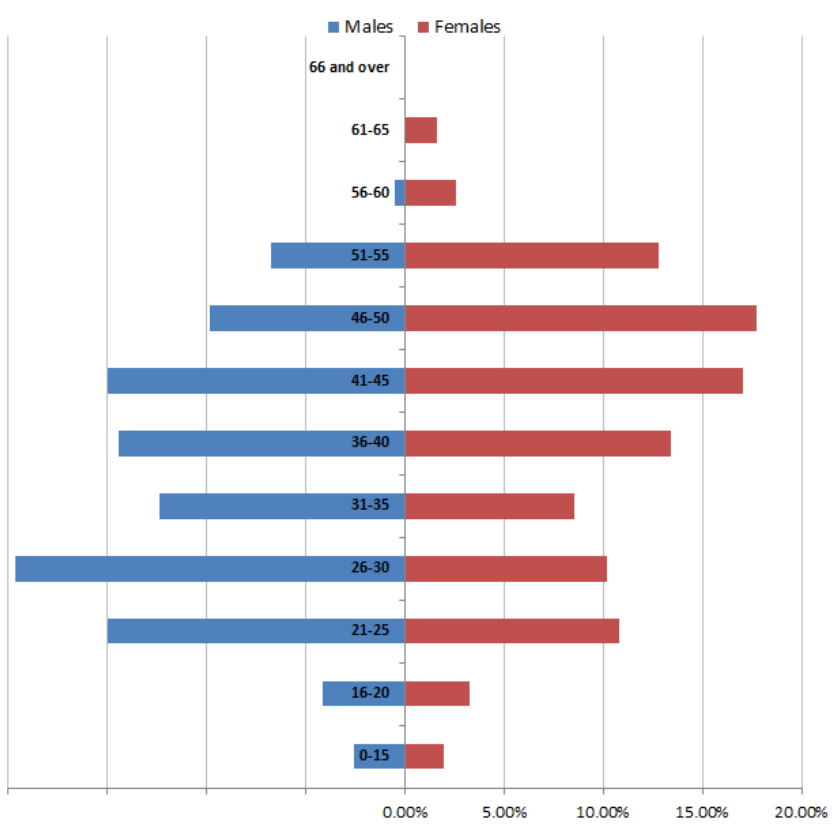

Figure 5. Age structure of the Ukrainian population in the Warsaw area, not weighted sample data (including imputed values)

Source: Own elaboration based on the RDS/CMR/2012 data base.

Life of Ukrainian migrants in Poland - at least those captured by the survey - is still largely oriented towards country of origin. Most of the migrants apply temporary migration strategies. Only small fraction of both men and women report to have dependents present in Poland. This is absolutely critical in the context of discussion presented in next sections. The same holds true in case of education. Ukrainian immigrants are relatively well educated with majority of persons having at least secondary education. It does not necessarily translate automatically into the level of income. Ukrainian men earn slightly more than Ukrainian women but there is only minor correlation between level of education and earnings (see Figure 9). This is to be attributed to the fact that majority of Ukrainian immigrants in Poland can be classified as working in the secondary sectors of the labor market (with construction, agriculture and household services as the most prominent examples).

Two critical levels of analysis refer to labor market status and indicators of fiscal position of Ukrainian immigrants ${ }^{22}$. Large majority of both males and females were working in 12 months preceding the survey, around 90 percent of them (in both cases) were working in last week. Share of unemployed was low and accounted to 8 percent in case of men and only 4 percent in case of women. Interestingly, it seems that due to introduction of new rules allowing relatively simple and easy access to the Polish labor market number of those being employed illegally was relatively low -

\footnotetext{
${ }^{21}$ Average number of stays in Poland is also much higher in case of female migrants.

${ }^{22}$ Note that the data on labor market status can be biased upwardly. Theoretically survey targeted those migrants who were economically active in preceding 12 months and thus it automatically excluded economically not active persons. However, risk of bias is lower due to two issues: first, collected data allowed for imputation of information collected on other household members (dependents and elderly); second, structure of the sample reflects knowledge on recent migration from Ukraine to Poland (Górny et al. 2010; Fihel et al. 2007).
} 
as high as 25 percent in case of males and roughly 20 percent in case of females. It is important to acknowledge that the survey methodology applied (RDS) was designed among others to capture both legal and illegal immigrants. Even if majority of immigrants is expected to work legally in Poland, minority of them claimed to pay taxes (48 percent in case of men and 41 percent in case of women). This can suggest that in reality Ukrainian immigrants are somehow active in the shadow zones of Polish economy. As could be expected following structural characteristics of Ukrainian immigrants, shares of those claiming any kind of social benefits in Poland are extremely low. The data on the issue will serve as a departure point for analysis presented in next sections.

The body of research on immigration to Poland, including Ukrainian immigrants, is growing but the papers on economic aspects of the inflow are scarce. This refers particularly to economic effects of immigration. To our knowledge it is the very first study looking at fiscal effects of immigrants' presence in the Polish society.

\section{DATA AND EMPIRICAL STRATEGY}

The analysis presented in sections to follow will be based predominantly on a unique data set on Ukrainian immigrants in Poland (precisely: in Warsaw area). As clearly indicated in the previous section there exists neither comprehensive nor reliable official data on immigration to Poland. Official register data portrays only (small) fraction of the phenomena, additionally they are not accessible as individual data ${ }^{23}$. Data sets commonly used in Western Europe for assessment of labor market incorporation or fiscal impacts of migration are of little help: the immigrant samples are too small or severely biased as clearly shown by outcomes of studies presented by OECD (2013) and Barrett and Maitre (2011) ${ }^{24}$.

For above reasons the only reasonable empirical strategy is to refer to data stemming from dedicated surveys. In this paper we will refer to a survey completed in Warsaw area in second half of 2012 based on RDS methodology ${ }^{25}$. Immigrant populations - particularly when irregular ones - are commonly referred to as rare, "hidden", or hard to reach. In case of such populations conventional sampling designs would produce potential biases. Thus, one of the research strategies applied for analysis of this kind of populations is to use auxiliary information during the research. These procedures are called "adaptive sampling strategies" and are based on the idea that the procedure for selecting subsequent units (to be included) in the sample depends on values of particular variables. In case of receiving country one of the most promising strategy is to refer to Respondent Driven Sampling which uses extensive information on migrant networks as a basis for estimation of sample characteristics and its representativeness ${ }^{26}$ (Seber and Thompson 1996; Turk and Borkowski 2005; Heckathorn 1997). Data collected include comprehensive information on around 500 Ukrainian immigrants, including their detailed migration trajectories, family situation (in Poland and Ukraine), labor market participation, remittances, social benefits claimed and migrant networks. Survey data was collected on individual basis but for sake of the analysis presented in this paper there were supplemented with the data on elderly and dependents household members present in

\footnotetext{
${ }^{23} 2011$ National Census data have not been revealed at time of writing of this paper.

${ }^{24}$ Both based on EU-SILC data.

25 For this reason all the administrative data as well as the data concerning the native population refer to 2012 as well.

${ }^{26}$ This kind of information is also used for weighting of variables. In following analyses we will use unweight data.
} 
Poland (imputed data). Two important features of the survey are necessary to comment on. First, survey encompassed exclusively Warsaw area and thus data presented are not representative on country level. Notwithstanding, due to structural characteristics of Ukrainian immigration and strong concentration of immigrants in Warsaw they can be used as a proxy of the general situation of Ukrainians in Poland. Second, in Polish case RDS proved to be very efficient in capturing all kind of immigrants, including settlement migrants, temporary workers and even students, legal and illegal ones (Górny and Torunczyk-Ruiz 2011). To our knowledge it is the only such comprehensive and methodologically reliable source of data to be used for analyses of immigrants' situation in Poland ${ }^{27}$.

In the following section we provide a detailed analysis of net fiscal position of Ukrainian immigrants in Poland. Thus we attempt to compare the transfers made to a given group considered against all payments made (taxes and contributions to the pension system). While doing that we will refer to all available data sources but still imposition of a number of assumptions is inevitable.

Following approach proposed by Dustman et al. (2010) and others we define the net government surplus (GSUR) as the difference between revenues (REV) and expenditures (EXP).

$$
G S U R=R E V-E X P=\sum_{i=1}^{N_{R}} r e v_{i}-\sum_{j=1}^{N_{E}} \exp _{j}
$$

Where total revenues are outcome of all kind of taxes, $\operatorname{rev}_{i}\left(i=1, \ldots, N_{R}\right)$ with $N_{R}$ denoting the total number of taxes and total expenditures are given by $\exp _{j}\left(j=1, \ldots, N_{E}\right)$ with $N_{E}$ denoting the total number of expenditures or services provided by the government. Further we can assess the net contribution of immigrants and natives by calculating the net fiscal position, NFP as difference between sum of revenues and expenditures related to particular group. If particular group contributes more to the system than it takes out in forms of benefits or services this difference should be larger than 0. Differently from Dustman et al. (2010) we consider difference rather than ratios of REV and EXP, for the fact that we aim at looking at one particular group and assess net costs of participation in Polish welfare system.

As in most of this kind exercises the critical issue lies in apportion revenues and expenditures (Gott and Jonston 2002; Dustmann et al. 2010; Barrett and Maitre 2011; OECD 2013). Due to the fact that in our case we base the assessment is based on the individual data we attempt to calculate the real value of payments/benefits. Alternative empirical strategy would imply spreading the costs and benefits among the immigrants and natives. This strategy, however, would be highly questionable considering the fact that - as it was shown above - aggregate immigration data in case of Poland is not reliable and can lead to seriously biased results (Barrett and Maitre 2011; OECD 2013). Empirical strategy applied poses other risks related to difficulties with apportion of particular costs or benefits to groups considered (and commonly acknowledged difficulties with self-reporting of particular data, e.g. income related information).

We start from apportion expenditures. According to Polish law (Act on Social Assistance) only persons holding Polish citizenship (and residing in Poland) and foreigners staying in Poland who

\footnotetext{
${ }^{27}$ To some extent we will refer to ECHP data and Households' Budget Survey data (2012) when it comes to comparison of immigrants and native-born persons. Note that due to the fact that data on Poles and Ukrainians are hardly comparable (e.g. individual vs. household levels) we will focus predominantly on assessment of immigrants' situation.
} 
holds a residence permit (or refugee status) are entitled to social benefits ${ }^{28}$. Following forms of social assistance are available: cash benefits and non-financial support. Cash benefits are granted as a rule - only to those individuals and families whose income per capita (net of taxes and health system payments) is lower than legally set threshold (recently PLN 542 per month in case of single household and PLN 456 per month in case of families). They can have following forms: 1) Permanent benefits granted to persons unable to work due to age or disability (and fulfilling the income criterion). The amount should not be lower than PLN 30 per month and equals the difference between the income criterion and actual personal income (in case of single households maximum value is as high as PLN 529 per month); 2) Periodical or temporary benefits also based on the income criterion and granted to individuals or families with not sufficient income due to illness, disability, unemployment etc. Rules concerning the value of benefit are similar to described above (with minimum value not lower than PLN 20 per month and not lower than $50 \%$ of the difference between income criterion and the actual personal income) (in case of single households maximum value is as high as PLN 418); 3) Purpose benefits (including special purpose benefit) granted with an aim to fulfill necessary needs of a person or family (e.g. costs of purchase of food, medicines, clothing etc.). Purpose benefits can be granted to persons/families over the income threshold; 4) Integration assistance granted to the refugees and foreigners granted the subsidiary protection in Poland. The assistance is provided for up to 12 months and includes mainly: benefits related to language learning, the payment of contribution to the health insurance, and specialized guidance. Nonfinancial support consists of many forms of help including: shelter, food or clothing, social work, care services, counseling (e.g. legal, psychological). In practice, the most important cost category relates to care services, see Table 2a (in the Annex).

Table 2a provides information on aggregated and per capita values as well as structure of financial and non-financial support in Poland and Mazowieckie region. From the presented data it follows that the most important (in terms of value of expenditures and expenses per capita) are permanent benefits, temporary benefits related to unemployment, provision of food and care services. Due to structural characteristics of the sample (very low share of children) as well as inability to apportion care related expenditures in further analyses we will focus predominantly on permanent and temporary benefits and unemployment related benefits.

Unemployed persons are entitled to unemployment benefits. In order to be granted unemployment benefit a given person has to register his/herself in a labor office (on poviat level), be able to prove working experience of at least 12 months in last 18 months before the day or registration and an income as high as the minimum remuneration as foreseen by the legislation ${ }^{29}$. The system of unemployment benefits is complicated because it depends on the situation on the local labor market. In case of local labor markets with relatively favorable labor market conditions the benefit is granted for 6 months, in case of poviats with high unemployment rates for maximum 12 months. The amount of unemployment benefit depends also on work experience and fulfilling additional conditions. According to the basic and main rule it equals PLN 761.40 in first three months and PLN 597.90 in the period of following months. Due to the fact that labor market conditions in Warsaw area are very favorable in terms of unemployment we further assume that maximum period of

\footnotetext{
${ }^{28}$ The same refers to citizens of the EU or EEA staying on the territory of Poland and holding a valid stay permit.

${ }^{29}$ And obviously he or she has to be without a job, ready to take up employment and lacking the possibility to be employed.
} 
unemployment benefit equals 6 months (in first three months PLN 761.40, in next three PLN 597.90 per month).

One of the most important expenditure categories relates to pensions. In 1999 a new pension system has been introduced in Poland. It was assumed that due to expected demographic changes the future pensioners would receive their pensions from at least two sources: the Social Insurance Institution (ZUS - public) and Open Pension Funds (OFE - private). A rule has been introduced to diversify choices available depending on age of given individual ${ }^{30}$. The whole system is a capital one and is based on individual pension accounts. As for now the contribution to the system is as high as 19.52 percent (including 3.5 percent paid for the open pension fund) of the income while the insured person paid as much as 9.76 percent $^{31}$.

Generally, individuals may benefit from the right to pension when they reach 60 (women) or 65 (men) years and are able to document contributory period as long as 20 and 25 years respectively. There are categories of people entitled to an earlier age pension (in case of women at age of 55, in case of men-60), mostly including those working in special or difficult conditions (there are several sub-systems working independent of the common system, including among others employees of police, army, farmers etc.). In 2012 new rules concerning retirement age have been introduced to the Polish legal system. According to them the retirement age was set as high as 67 years for both sexes, however there is a gradual path towards this threshold foreseen starting in 2013 as well as early retirement scheme was abolished ${ }^{32}$. In further analyses we assume that immigrants follow old rules concerning age of retirement and costs of their pensions are exclusively born by the state (e.g. they are treated as members of the PAYG part of the system).

Estimation of the costs of education and health services are beyond the scope of this paper. Considering that we refer to commonly acknowledged as reliable data provided by OECD (OECD 2012a, OECD 2012b). According to OECD (2012a) costs of education in Poland are much higher than the OECD average and can be estimated at: USD 5,303 annually for primary education; USD 5,026 annually for secondary education; and USD 7,776 annually for tertiary education (all data for 2009, in equivalent USD PPP). In case of health care the estimation of health expenditures per capita is far more complicated due to presence of various insurance schemes and strong dependence of care value on health conditions and age of a given person. Thus all average values can be seriously biased $^{33}$. As for 2010 the average annual spending per person in Poland was estimated at EUR 1,068 (PPP) as compared to EUR 2,171 as the EU-27 average (OECD 2012b). In further analyses we use above provided values transferred into PLN.

A critical issue in case of public expenditures is the allocation of public goods. Due to the fact that in case of Poland immigrants represent very small portion of the total population we suggest not to consider pure public goods in further estimates (e.g. costs of national defense). For this reasons estimates presented in the next section can be downwardly biased (see Coleman and Rowthorn 2004; Dustmann et al. 2010 for discussion on that issue).

\footnotetext{
${ }^{30}$ Persons born after 31 December, 1968 were obliged to join one of the open pension funds, persons born between 31 December, 1948 and 1 January, 1969 were able to choose whether to contribute to the open pension funds or exclusively to the Social Insurance Institution, while persons born before 1 January, 1949 paid their contribution solely to the Social Insurance Institution.

${ }^{31}$ This rule is under serious discussion recently and can change in near future as well as the whole architecture of the system.

${ }^{32}$ Due to the fact that this condition does not impact on short-time outcomes of analysis provided it will not be taken into consideration.

${ }^{33}$ But it is worth noting that according to the OECD data in case of Poland only 6 per cent of the total expenditures are related to longterm care which is the most strongly linked to the process of population ageing and the age structure of population itself (OECD $2012 \mathrm{~b})$.
} 
As for revenue side we consider direct taxes and all related payments. The Polish tax system has been developing gradually since the beginning of socio-economic transition. In last few years the main drivers of changes were: a tendency to encourage foreign investors (this was one of the reasons why the corporate income tax was reduced from 40 to 19 per cent) and harmonization of Polish tax law with the EU legislation. Polish tax system includes:

1. Direct taxes, among others: personal income tax, corporate income tax, inheritance and donation tax, tax on civil law transactions, agricultural tax, forest tax, and real property tax;

2. Indirect taxes, mainly Value Added Tax, excise duty, and tax on gambling ${ }^{34}$.

Due to specific forms of migration considered in this paper, in case of direct taxation the most important role has the personal income tax. In 2009 the new tax scale has been introduced with two tax rates $18 \%$ and $32 \%$, and tax threshold as high as PLN 85,528 PLN and the amount decreasing the tax equaled to PLN 556.02 PLN (with tax-free amount as high as PLN 3,091). Due to the lack of data on structure of expenses in Poland, indirect taxation will not be considered. Notwithstanding it poses an important challenge for future research.

The basis for analysis presented in next section provides self-reported data on both consumption of services as well as payments to the state treasure. For the sake of robustness checking a set of alternative scenarios will be presented, Table 2 .

Table 2. Net fiscal position of Ukrainian immigrants in Poland - scenarios considered

\begin{tabular}{|l|l|l|}
\hline Scenario I & $\begin{array}{l}|c| \\
\text { Payments of taxes and other payments (social } \\
\text { security payments, health security payments) } \\
\text { calculated only for those claiming taxes payment in } \\
\text { Poland (calculations based on reported values) }\end{array}$ & $\begin{array}{l}\text { Only those immigrants who self-reported the take-up of social } \\
\text { remittances are considered (calculations based on reported } \\
\text { values) }\end{array}$ \\
\hline Scenario II & $\begin{array}{l}\text { Payments of taxes and other payments (social } \\
\text { security payments, health security payments) } \\
\text { calculated for those migrants who were staying in } \\
\text { Poland legally and were actually working } \\
\text { (calculations based on reported and imputed } \\
\text { values) }\end{array}$ & $\begin{array}{l}\text { All immigrants theoretically eligible are considered. Two level } \\
\text { conditions were applied: first, only persons legally staying in } \\
\text { Poland were considered as eligible, and second, specific rules } \\
\text { were applied (persons below income threshold in case of cash } \\
\text { benefits, persons at retirement age in case of pensions, } \\
\text { persons with dependents in case of children benefits) } \\
\text { (calculations based on reported and imputed values) }\end{array}$ \\
\hline Scenario III & $\begin{array}{l}\text { Payments of taxes and other payments (social } \\
\text { security payments, health security payments) } \\
\text { calculated for those migrants who were actually } \\
\text { working (i.e. same as scenario II but irrespective of } \\
\text { the legal status of a given person) (calculations } \\
\text { based on reported and imputed values) }\end{array}$ & $\begin{array}{l}\text { All immigrants theoretically eligible are considered } \\
\text { irrespective their legal status (i.e. same as scenario II except } \\
\text { for the legal status condition) (calculations based on reported } \\
\text { and imputed values) }\end{array}$ \\
\hline
\end{tabular}

* Indirect taxes not considered due to lack of data on consumption structure

Source: Own elaboration.

\footnotetext{
${ }^{34} \mathrm{It}$ is worth noting that there is clear tendency visible towards more emphasis on the indirect side of taxation in Poland (MAiC 2012). Recently, indirect taxes are responsible for around 60-65 per cent of the tax incomes - CSO).
} 
Scenarios considered differ particularly with respect to the source of information (self-reported or imputed). Thus, Scenario II with imputation based on the full set of information available is to be treated as the most reliable. Scenario III assumes additionally that all immigrants are legalized and in that sense it can be useful for policy considerations.

In order to provide a comparison between immigrants and the natives the EU-SILC data has been used to obtain the information on the net fiscal position of Polish citizens. As suggested above the data on the native population utilized in section $V$ is not fully comparable with the RDS data because they refer to all households members surveyed (or precisely: persons aged 16 and over) and not to self-selected representatives of Ukrainian households. In this case only reported values has been used to calculate annual contributions and benefits obtained. On the revenue side payment of taxes, social security payments and health security payments have been considered. The expenditure side included all kind of social benefits (unemployment benefits, pensions, sickness benefits, disability benefits or education-related allowances) as well as costs of the health care and education calculated on the basis of the OECD data (OECD 2012a, OECD 2012b). The sample complied only those persons who reported both incomes, contributions and benefits and was as high as 8733 .

\section{RESULTS AND DISCUSSION}

Results presented and discussed below represent the first step towards understanding fiscal impacts of immigration to Poland. Outcomes should not be generalized to the total immigrant population because of two facts. First, data used refer to one particular immigrant group which - even if important in quantitative terms - does not reflect the whole complexity of recent immigration to Poland. Second, we limit the analysis to static approach only and analyze fiscal position of immigrants as for 2012. Thus, dynamic approach to this issue still poses a challenge for future research and will be discussed shortly in the very end part of this section.

Main outcomes of analysis described methodologically in the previous section are presented below, Figure 6.

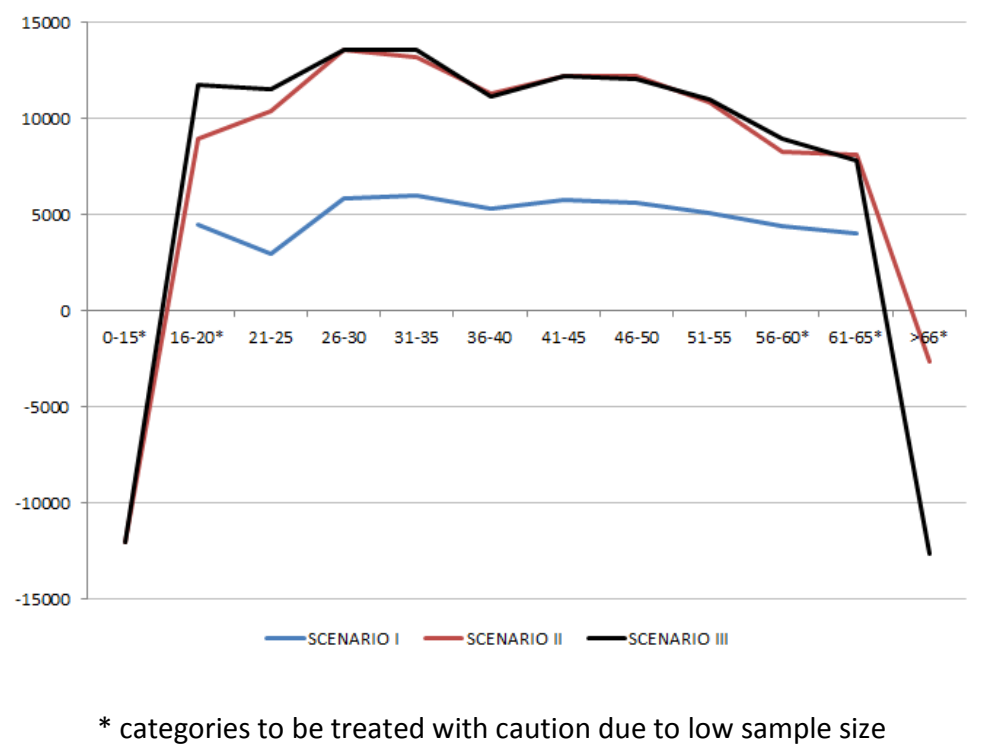


Figure 6. Net fiscal position of Ukrainian migrants in Poland, by age groups, in PLN (annually)

Source: Own elaboration based on RDS/CMR/2012 data.

Figure 6 presents outcomes of three scenarios considered by age of immigrants. The first scenario is based on self-reported values with respect to both revenues as well as benefits (no imputation). For this reason it is rather conservative in terms of both fiscal sides considered. According to the data presented, presence of Ukrainian immigrants in Poland brings clearly positive effects for the state budget independent of age. This is not surprising considering the fact that original sample did not include persons aged less than 15 years and more than 66 years. This is why in order to properly assess the fiscal impacts of Ukrainian immigration it is necessary to refer to Scenario II. Nevertheless, it is worth noting that with regard to Scenario I the curve depicting net fiscal position is unexpectedly flat.

The second scenario considered includes imputed values for dependents and elderly present in Poland, but also for those who claimed legal work but not necessarily payment of taxes (or refused to answer this question). In this case picture changes remarkably with clearly negative values for persons aged $<15$ and $>66$. In the latter case, however, negative values are relatively low due to low value of pensions imputed. Shape of the curve is similar to reported in many other studies looking at fiscal impacts of immigration (Auerbach and Oreopoulos 1999; Storesletten 2000; OECD 2013), but importantly the net fiscal contribution of immigrants lasts relatively long (until 65 years of age). Additionally, the overall fiscal impact of immigration is unequivocally positive (both due to ratio of people in productive and not productive age as well as due to relatively high positive net revenues in case of persons aged 16-65).

Last but not least, Scenario III assumes legalization of the Ukrainian immigrants in Poland with important effects on the revenue and expenditure side. Complementary to Figure 6, Figure 7 presents differences between scenarios under analysis.
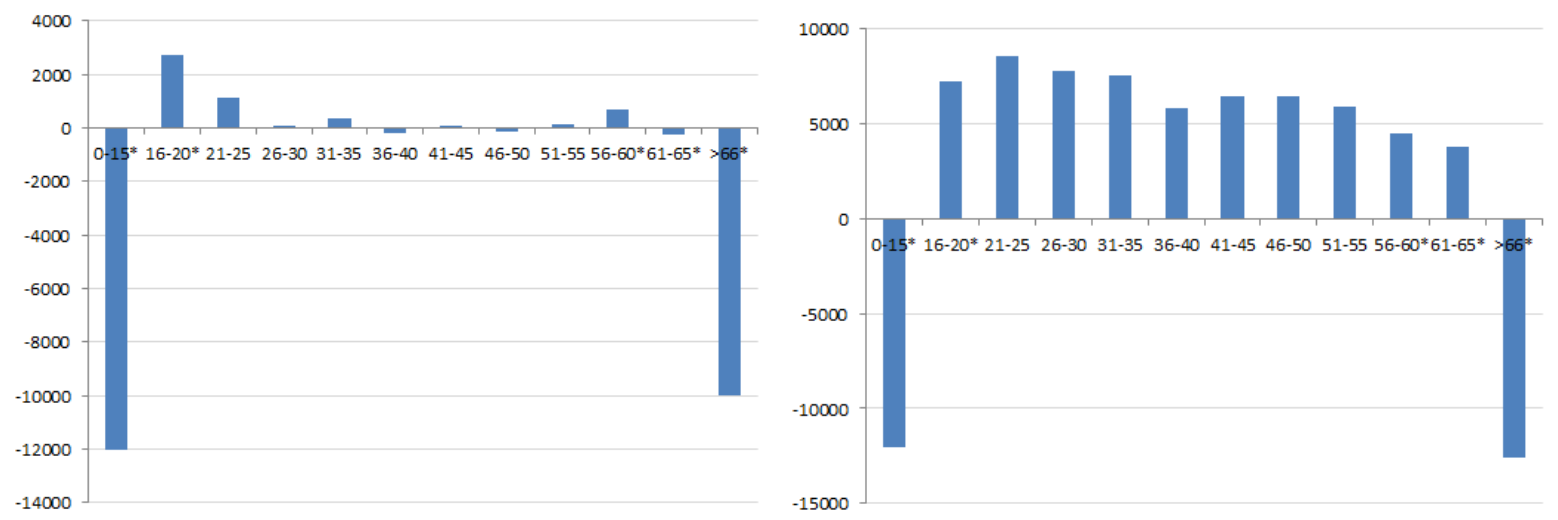

* categories to be treated with caution due to low sample size

Figure 7. Comparison of scenarios: scenario III vs. scenario II (left panel) and scenario III vs. scenario I (right panel), by age groups, in PLN (annually)

Source: Own elaboration based on RDS/CMR/2012 data. 
Interestingly, due to the fact that already large share of Ukrainian immigrants in Poland work (quasi) legally, differences between Scenario II and III are not impressive and follow mainly from inclusion of dependents / elderly and pension costs for persons staying legally in Poland (but with clearly negative impact on the aggregated outcome). Far more interesting seems the comparison between Scenario III and I. Similarly to the previous case, Figure 7 (right panel) reveals negative differences in case of youngest and oldest age groups. Notwithstanding, huge differences are noted in case of other age groups. As a consequence, complete legalization of immigrants from Ukraine in Poland is expected to significantly increase the tax base and extend the revenue side. This observation has important policy implications. Even if recent changes in Polish migration policy managed to increase the share of Ukrainians staying in Poland legally ${ }^{35}$, there is still a space for introducing measures preventing them from being employed in the shadow economy (with no taxed or only partially taxed earnings).

Another interesting issue commonly discussed in empirical studies refers to the comparison between net fiscal position of immigrants and native-born, Figure 8. From the data presented below it follows that Ukrainian immigrants not only do make a positive contribution to the Polish public finances but it is higher than in case of the native-born. This holds true in case of all scenarios considered, however, in case of the Scenario I (only reported values considered) the figures for age groups 31-60 are similar and the differences in case of younger and older age brackets result from obvious differences in age composition of Ukrainian immigrants and the native population as discussed above.

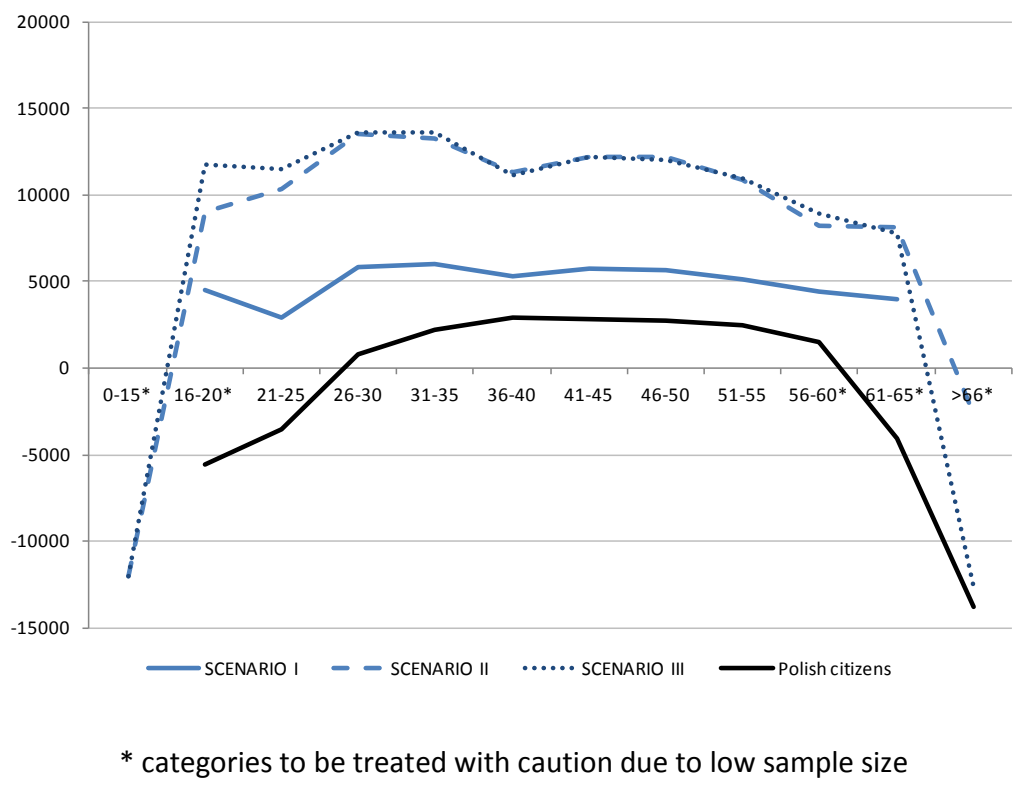

Figure 8. Net fiscal position of Ukrainian migrants in Poland, by age groups and Polish citizens, in PLN (annually)

Source: Own elaboration based on RDS/CMR/2012 data and 2012 EU-SILC data.

\footnotetext{
${ }^{35}$ In the survey legality of stay in Poland was controlled by documents reported by given persons entitled to stay as well as direct question on that issue.
} 
Generally, presented results show that Ukrainian immigrants in Poland are unambiguously net fiscal contributors. With respect to this, all scenarios considered provide similar results (with only small differences resulting from inclusion/exclusion of dependents and elderly). This kind of picture is remarkably different from empirical evidence presented in section II, or at least large part of it. To disentangle this difference one needs to refer to previous discussion on factors influencing net fiscal position (Section II and Figure 2) and main structural characteristics of Ukrainian immigrants in Poland (Section III and IV, and Table 1):

1) Importance of socio-demographic characteristics.

From the empirical evidence it follows that age, gender and education can explain to large extent the net fiscal position of immigrants (and particularly the difference between immigrants and natives). Polish experience challenges this outcome. Ukrainian immigrants in Poland are generally young, but - particularly in case of women - not as young as expected, Table 1. Impact of both age and gender on fiscal position is not unequivocal, Figure 8.
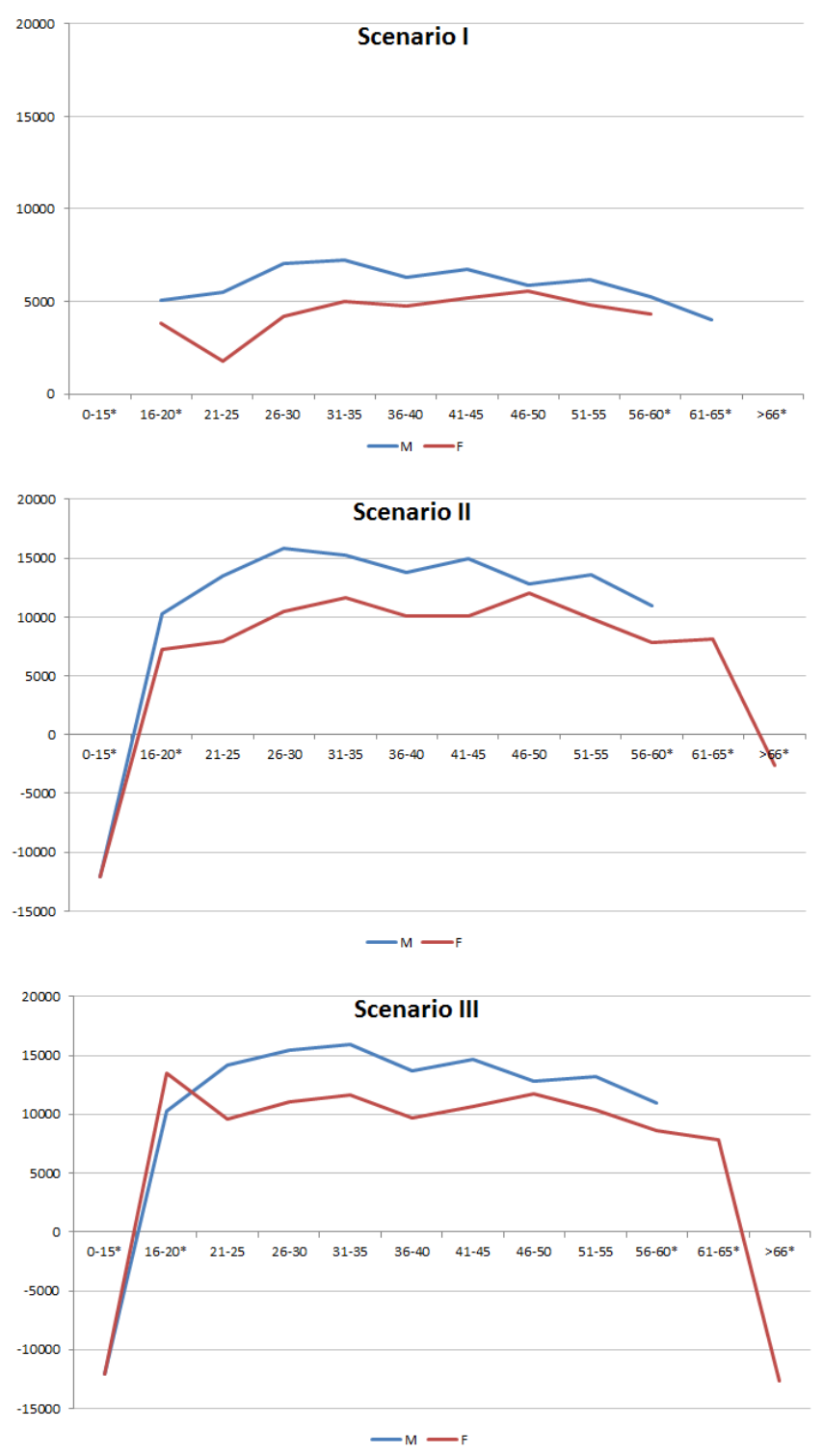

* categories to be treated with caution due to low sample size 
Figure 9. Net fiscal position of Ukrainian migrants in Poland, by age groups and sex, in PLN (annually)

Source: Own elaboration based on RDS/CMR/2012 data.

Figure 9 shows that the distribution of net fiscal position by age is relatively flat. Additionally, differences between men and women are strikingly small. This picture is to a large extent the outcome of particular income position of both genders, Figure 10.

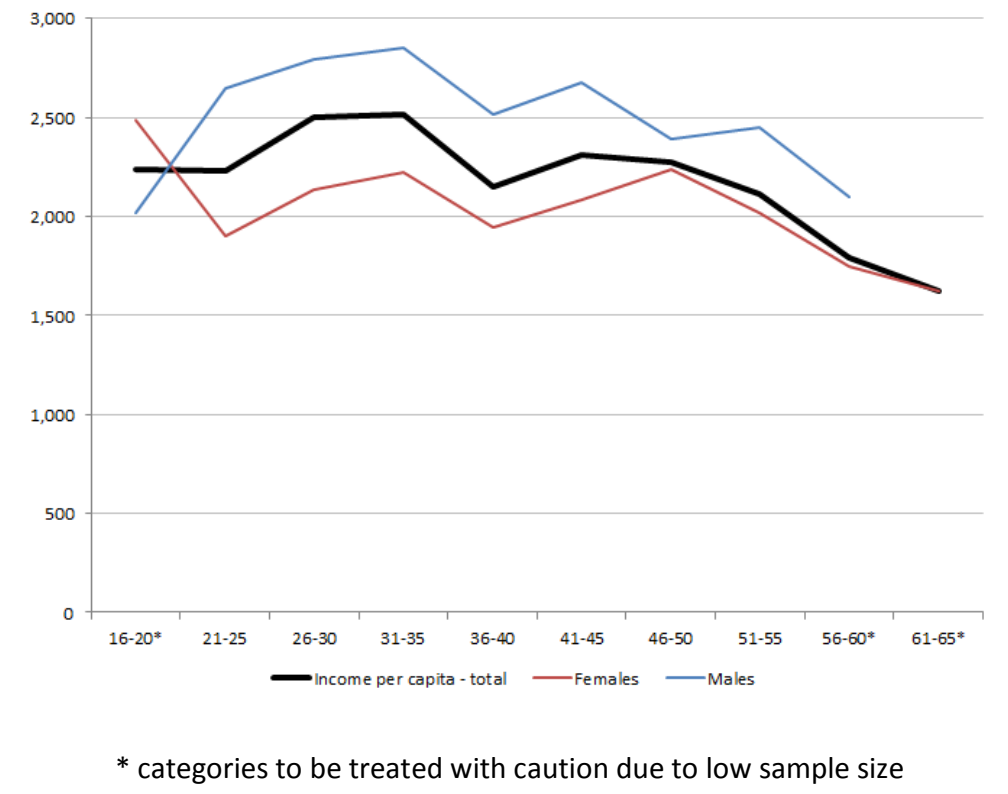

Figure 10. Average monthly net income of Ukrainian migrants in Poland, by age groups, in PLN

Source: Own elaboration based on RDS/CMR/2012 data.

Figure 10 shows the income distribution by age for the total and with respect to gender. The average income is relatively low as for standards in Warsaw area (according to Sedlak \& Sedlak 2013 the median net income equaled around 3,883 PLN), but similar to the average income for persons employed in Polish economy (2,763 PLN for men and 2,072 PLN for women as compared to 2,290 PLN - CSO data) and significantly higher than the minimum wage (in 2012 around 1,000 PLN net). As expected the highest income was noted for persons aged 26-40 but remains relatively high also for older persons. This is particularly true for women due to their specific forms of engagement in the Polish labor market (see Section III). For the same reasons, income gap between men and women diminishes with age. Even more interesting seems the effect of education on the net fiscal position, Figure 11. 


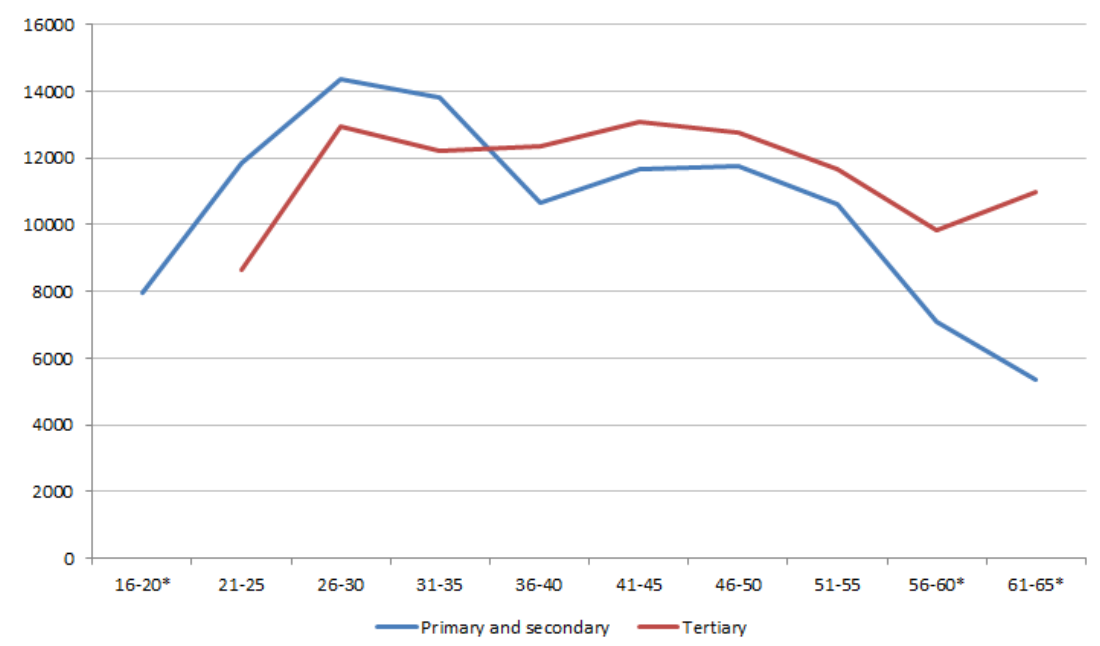

Figure 11. Net fiscal position of Ukrainian migrants in Poland, by age groups and level of education, in PLN (annually)

Source: Own elaboration based on RDS/CMR/2012 data.

Picture presented above is interesting in the context of large body of literature on labor market absorption of immigrants. Income curves of persons with primary and higher levels of education are very close. Additionally, while the net position of women is similar irrespective the level of education, better educated men are - on average - able to earn more and this is why their fiscal position is more favorable. Thus, net income and net fiscal position of Ukrainian immigrants in Poland is hardly a function of their socio-demographics but rather particular forms of labor market incorporation.

\section{2) Type of migration.}

What makes the Polish case very unique - and politically interesting - is the type of migration observed. From the Table 1 it follows that Ukrainian immigrants in Poland are not only to be presented in terms of typical labor migration, but present also low or extreme low level of benefits up-take. Additionally, according to migrants themselves their stay in Poland is predominantly temporary. Around 16 percent of migrants stated an intention to stay for more than 3 years (but not permanently), another 15 percent wanted to settle in Poland. It is commonly acknowledged that immigrants tend to often change their plans but there is no mistake in perceiving Ukrainian immigration to Poland as predominantly temporary phenomenon.

Thus Ukrainian immigration to Poland seems to be "very attractive" from the political point of view. Immigrants represent source of net state income in the short-term and will hardly burden state budget in the future. If we assume that temporary migration schemes will last for next years or decades, this type of migration may present a relief to the Polish pension system as well. Note that with respect to the type of migration Ukrainians are quite similar to A8 immigrants in the UK (with some differences respecting settlement plans). Thus this is not coincidence that Dustmann et al. (2011) reported unequivocal positive net fiscal position of A8 immigrants in this country. 


\section{3) Institutional background.}

Last but not least, analysis presented brings a few important lessons in terms of institutional design being commonly emphasized as one of the main factors responsible for labor market incorporation and net fiscal position of immigrants. First, simplified procedure streamlined many immigrants into legal forms of employment or, at least, gave them a chance to stay in Poland legally. A lot needs to be done in terms of the tax base but important step forward was made already. Second, Polish welfare system is not perceived as generous nor friendly one (particularly for foreigners). As a consequence structure of incoming migrants to Poland is quite specific as for European standards. Numbers of refugees or asylum seekers are low or very low (roughly few thousands applications annually in recent years with only a dozen statuses granted), so is the number of incoming family members. In this paper we focus on Ukrainian immigrants but also other important immigrant groups - Vietnamese, Belarusians, and Chinese - are coming to Poland not attracted by its welfare system but rather work opportunities or chances to start their own business. We should not underestimate this factor while assessing net fiscal position of immigrants.

Analysis presented misses one important point to be assessed empirically in the future. It refers to analysis of long-term consequences of presence of immigrants in form of dynamic assessment. We plan to execute this kind of analysis in the future but one needs to be aware of many problems related. Except for obvious methodological and technical difficulties described already in Section II, it will be necessary to look carefully at migration strategies and the Polish pension system. Ukrainian immigration in Poland is so far predominantly temporary phenomenon. Application of Generational Accounting (or similar approaches) would demand clear assumptions concerning future of Ukrainians in Poland and all forecasts seem highly implausible at recent state of knowledge. Second, Polish pension system is under constant discussion and a clear vision of the future of the system is apparently lacking (the same refers to the health system). This makes every dynamic exercise even more challenging.

\section{CONCLUDING REMARKS}

Due to the scale of immigration to well developed economies as well as commonly acknowledged welfare crisis in many countries around the globe, immigration impacts on the welfare system of host countries are considered as one of the most important and difficult issues in general debate on migration. For this reason it seems critical to assess the fiscal impacts of immigration and to answer the question about factors responsible for given fiscal position of immigrants. As shown in this paper, answering these questions is not trivial in neither theoretical nor empirical terms. Most of theoretical models at hand suffer from simplistic assumptions shaping seriously the final outcomes. Empirical studies provide mixed results. Notwithstanding, it is possible to make a general assessment.

Aggregate fiscal impacts of immigration are small (in GDP terms) and their sign depends on structure of incoming migrants and structural conditions in a given country. Immigrants tend to have a less favorable net fiscal position than natives but it is not necessarily due to higher dependency on welfare but rather due to lower taxation and social security contribution (as functions of generally lower incomes). Moreover, most of this gap disappears when controlling for socio-demographic 
characteristics and, particularly, labor market status. Empirical literature reveals that the net fiscal position of immigrants depends to some extent on their socio-demographics, but importance of those factors (particularly: level of education) seems to be overestimated. Instead, what really matters is the institutional framework at destination and structure (type) of migration. Notwithstanding, immigrants generate relatively large - although transitory - contribution to the pension systems and this contribution could not be offset by - generally - higher dependency on social transfers. This is why most of the dynamic approaches looking at the phenomenon in the longterm perspective provide far more positive picture than static ones (see also Kaczmarczyk and Rapoport 2014).

Presented empirical analysis - the very first attempt to assess fiscal impacts of migration into Poland - shows that Ukrainian immigrants in Poland are unambiguously net fiscal contributors. All scenarios considered - from the baseline one to the one assuming full legalization of immigrants staying in the country - provide similar results. Such a positive outcome is due to a few factors. First, generally positive assessment of fiscal position of Ukrainian immigrants in Poland is a result of favorable characteristics of incoming immigrants: immigrants are relatively young and on average well educated. Second, very low share of persons who claim up-take of social benefits results from particular migration strategies in work. Most of Ukrainian immigrants in Poland are to be described in terms of temporary labor migrants. This feature, however, to a large extent is a function of modes of labor market incorporation (as well as demand on foreign labor) and structural characteristics of the Polish welfare state.

Situation of Poland as emigration-immigration country is specific but still outcomes of the analysis presented allow to draw a few important policy lessons. First, in future many European countries will need more immigrants to sustain their welfare systems. The inflow of those "new immigrants", however, has to be more selective to maximise positive impacts of immigration. Our study shows clearly that type of migration does matter immensely. Labor migrants or target earners tend to integrate easily and bring serious benefits in terms of taxes and related payments. On the other hand, family members or refugees tend to assimilate into welfare. Assimilation out of welfare is still feasible but it is a long process and demands well-tailored labor-market policies. This is important for these categories of immigrants are inescapable. Second, explanation should go beyond the traditionally considered factors with level of education as the most prominent example (with low skilled workers assumed to be net burden in fiscal terms). Many studies, including ours as well as studies on A8 immigrants in the UK, show that what really matters is the "labor market value", strongly dependent on the host labor market and its structure, and largely irrespective skill level of incoming immigrants. Third, the process of labor market incorporation depends not only on the socio-demographic characteristics of immigrants but also on labor market and welfare institution in the host economy. The structural framework is responsible for attracting particular types of immigrants but also creates incentives or disincentives to integrate, with particular consequences in fiscal terms but also with respect to the well-being of immigrants. 


\section{REFERENCES}

Akbari, Ather S. 1989. The Benefits of Immigrants to Canada: Evidence on Tax and Public Services. Canadian Public Policy 15(4): 424-435.

Andrén, Daniela and Thomas Andrén. 2012. Never give up? The persistence of welfare participation in Sweden. Discussion Papers 5, Central European Labour Studies Institute (CELSI).

Auerbach, Alan J. and Philip Oreopoulos. 1999. The Fiscal Impact of U.S. Immigration: A Generational Accounting Perspective. Paper presented at the NBER Tax Policy and the Economy conference.

Barrett, Alan and Bertrand Maitre. 2011. Immigrant Welfare Receipt across Europe. IZA Discussion Papers No. 5515, Institute for the Study of Labor (IZA).

Barrett, Alan and Yvonne McCarthy. 2008. Immigrant and Welfare Programmes: Exploring the Interactions between Immigrant Characteristics, Immigrant Welfare and Welfare Policy. Oxford Review of Economic Policy 24(3): 543-560.

Berry R. Albert and Ronald Soligo. 1969. Some Welfare Aspects of International Migration. Journal of Political Economics 77(5): 778-794.

Bird, Edward J., Kayser, Hilke, Frick, Joachim R. and Gert G. Wagner. 1999. The Immigrant Welfare Effect: TakeUp or Eligibility? IZA Discussion Paper 66.

Blume, Kraen and Mette Verner. 2007. Welfare dependency among Danish immigrants. European Journal of Political Economy 23(2): 453-471.

Boeri, Tito, Hanson, Gordon and Barry McCormick (eds.). 2002. Immigration Policy and the Welfare System. Oxford: Oxford University Press.

Boeri, Tito. 2010. Immigration to the Land of Redistribution. Economica 77(308): 651-687.

Bonin, Holger, Raffelhauschen Bernd and Jan Walliser. 2000. Can Immigration Alleviate the Demographic Burden. FinanzArchiv 57(1).

Bonin, Holger. 2002. Eine fiskalische Gesamtbilanz der Zuwanderung nach Deutschland. IZA Discussion Paper No. 516. Institute for the Study of Labor (IZA).

Bonin, Holger. 2006. Der Finanzierungsbeitrag der Auslaender ze den deutschen Staatsfinanzen: Eine Bilanz fuer 2004. IZA Discussion Paper No. 2444. Institute for the Study of Labor (IZA).

Borjas, George J. 1987. Self-selection and the earnings of immigrants. American Economic Review 77: 531-553.

Borjas, George J. 1994. The Economics of Immigration. Journal of Economic Literature 32: 1667-1717.

Borjas, George J. 1999. Immigration and welfare magnets. Journal of Labour Economics 17: 607-637.

Borjas, George J. and Lynette Hilton. 1996. Immigration and the Welfare State: Immigrant Participation in Means- Tested Entitlement Programs. The Quarterly Journal of Economics 112(2): 575-604.

Borjas, George J. and Stephen J. Trejo. 1991. Immigrant Participation in the Welfare System. NBER Working Papers 3423.

Borjas, George J. and Stephen J. Trejo. 1993. National origin and immigrant welfare recipiency. Journal of Public Economics 50(3): 325-344.

Brücker, Herbert, Epstein, Gil S., McCormick, Barry, Saint-Paul, Gilles, Venturini, Alessandra, and Klaus Zimmermann. 2002. Managing Migration in the European Welfare State. In: Boeri, Tito, Hanson, Gordon and Barry McCormick (eds.). Immigration Policy and the Welfare System. Oxford: Oxford University Press. 
Castronova, Edward J., Kayser, Hilke, Frick, Joachim and Gert G. Wagner. 2001. Immigrants, Natives and Social Assistance: Comparable Take-Up Under Comparable Circumstances. International Migration Review 35(3): 726-748.

Chand, Sheetal and Martin Paldam. 2004. The economics of immigration into a Nordic welfare state - and a comparison to an immigration state and a guest worker state. Economics Working Papers 2004-4, School of Economics and Management, University of Aarhus.

Chojnicki, Xavier and Lionel Ragot. 2011. Impacts of Immigration on Aging Welfare-State. An Applied General Equilibrium Model for France. CEPII WP No 2011-13.

Chojnicki, Xavier. 2004. The economie impact of immigration for the host countries. Brussels Economic Review 47(1): 9-28.

Coleman, David and Robert Rowthorn. 2004. The Economic Effects of Immigration into the United Kingdom. Population and Development Review 30(4): 579-624.

Collado, Dolores, Iturbe-Ormaetxe, Inigo, and Guadelupe Valera. 2004. Quantifying the Impact of Immigration on the Spanish Welfare State. International Tax and Public Finance 11: 335-353.

DeVoretz, Don. 2006. Immigration Policy: Methods of Economic Assessment. International Migration Review 40(2): 390-418.

Djajic, Slobodan and Michael S. Michael. 2009. Temporary Migration Policies and Welfare of the Host and Source Countries: A Game-Theoretic Approach. CESifo Working Paper No. 2811.

Djajic, Slobodan. 1997. Emigration and welfare in an economy with foreign capital. Journal of Development Economics 56(1998): 433-445.

Djajic, Slobodan. 2009. On the welfare implications of temporary and permanent immigration. Bank i Kredyt 40(5): 49-60.

Dustmann, Christian, Frattini, Tommaso and Caroline Halls. 2010. Assessing the Fiscal Costs and Benefits of A8 Migration to the UK. Fiscal Studies 31(1): 1-41.

Duszczyk, Maciej, Góra, Marek and Pawel Kaczmarczyk. 2013. Costs and Benefits of Labour Mobility between the EU and the Eastern Partnership Partner Countries. Country Report - Poland. Bonn: IZA.

Ekberg, Jan. 1999. Immigration and the public sector: Income effects for the native population in Sweden. Journal of Population Economics 12: 411-430.

Fihel, Agnieszka, Górny,Agata, Grzymała-Kazłowska, Aleksandra, Kępińska, Ewa and Aneta Piekut. 2007. Od zbiorowości do społeczności: rola migrantów osiedleńczych w tworzeniu się społeczności imigranckich w Polsce. [From Settlement Towards Community: the Role of Settlement Migrants in the Formation of Migrant Communities in Poland.] CMR Working Papers, Nr 27/(85). Warsaw: CMR.

Fihel, Agnieszka, Kaczmarczyk, Pawel, and Renata Stefanska. 2013. Recent Trends in International Migration in Poland. Central and Eastern European Migration Review 1(1): 69-90.

Freeman, Gary. P. 1986. Migration and the Political Economy of the Welfare State. Annals of the American Academy of Political and Social Science 485: 51-63.

Fuest, Clemens and Marcel Thum. 1999. Welfare Effects of Immigration in a Dual Labor Market. CESifo Working Paper No. 215.

Gaston, Noel and Gulasekaran Rajaguru. 2013. International migration and the welfare state revisited. European Journal of Political Economy 29: 90-101.

Górny, Agata and Sabina Toruńczyk-Ruiz. 2011. Integration of migrants from the perspective of social ties and neighbour relations. CMR Working Paper, Nr 48(106). Warsaw: CMR. 
Górny, Agata, Kindler, Marta, Piekut, Aneta, Stefańska, Renata and Monika Szulecka. 2010. Wybrane aspekty integracji imigrantów: w poszukiwaniu mechanizmów sprzyjających dalszemu napływowi cudzoziemców do Polski. In: Górny A., I. Grabowska-Lusińska, M. Lesinska, M. Okólski. Transformacja nieoczywista. Polska jako kraj imigracji. Warsaw: Wydawnictwa Uniwersytetu Warszawskiego. pp.188-231.

Gott, Ceri and Karl Johnston. 2002. The Migrant Population in the UK: Fiscal Effects. London: Home Office.

Griswold, Daniel. 2012. Immigration and the Welfare State. Cato Journal 32(1): 159-174.

Hansen, Jorgen and Magnus Lofstrom. 2003. Immigrant Assimilation and Welfare Participation: Do Immigrants Assimilate Into or Out of Welfare? The Journal of Human Resources 38(1): 74-98.

Hansen, Jorgen and Magnus Lofstrom. 2009. The dynamics of immigrant welfare and labor market behaviour. Journal of Population Economics 22: 941-970.

Heckatorn, Douglas D. 1997. "Respondent-Driven Sampling: A New Approach to the Study of Hidden Populations." Social Problems 44(2): 11-34.

Heckatorn, Douglas D. 1997. Respondent-Driven Sampling: A New Approach to the Study of Hidden Populations. Social Problems 44(2): 11-34.

Huddle, Donald. 1993. The Costs of Immigration. Houston: Rice University (mimeo).

Kaczmarczyk, Pawel and Hillel Rapoport. 2014. Stereotype 4: Migrants undermine our welfare systems. In: Fargues, Philippe (ed.) Is What We Hear About Migration Really True? Questioning Eight Stereotypes. Florence: EUI, pp. 33-42.

Kaczmarczyk, Pawel et al. 2015. Recent Trends in International Migration in Poland The 2014 SOPEMI Report. Warsaw: CMR UW (unpublished manuscript).

Kaczmarczyk, Pawel. 2013. Are immigrants a burden for the state budget? Review paper. RSCAS EUI Working Papers 2013/79. Florence: European University Institute.

Kaczmarczyk, Pawel. 2010. Poakcesyjne migracje Polaków - próba bilansu. Studia Migracyjne - Przeglqqd Polonijny 4: 5-36.

Kaczmarczyk Paweł. 2008. Cudzoziemscy pracownicy w Polsce - skala, struktura, znaczenie dla polskiego rynku pracy. In: (ed.) P. Kaczmarczyk i M. Okólski. Polityka migracyjna jako instrument promocji zatrudnienia i ograniczania bezrobocia. Warsaw: CMR. s.50-75.

Krugman, Paul. 1991. Geography and Trade. Cambridge: Cambridge University Press.

Lee, Ronald and Timothy Miller. 1998. The current fiscal impact of immigrants: Beyond the immigrant household. In J. Smith and B. Edmonston (eds.) The Immigration Debate. Washington D.C.: National Academy Press.

Lee, Ronald and Timothy Miller. 2000. Immigration, Social Security, and Broader Fiscal Impacts. American Economic Review 90(2): 350-354.

MAiC. 2012. Polska 2030. Trzecia fala nowoczesnosci. Dlugookresowa Strategia Rozwoju Kraju. Warsaw: Ministerstwo Administracji i Cyfryzacji.

Michael, Michael S. 2003. International migration, income taxes and transfers: a welfare analysis. Journal of Development Economics 72(2003): 401-411.

Michael, Michael S. 2011. Welfare Effects of Immigration Policies in the Presence of Skilled, Unskilled Labor and Capital Mobility. Review of Development Economics 15(4): 651-663.

Michael, Michael S. and Panos Hatzipanayotou. 2000. Welfare Effects of Migration in Societies with Indirect Taxes, Income Transfers and Public Goods Provision, CESifo Working Paper No. 347. 
Michael, Michael S. and Panos Hatzipanayotou. 2005. Migration, Tied Foreign Aid and the Welfare State. CESifo Working Paper No. 1497.

Monso, Olivier. 2002. L'immigration: quels effets sur les finances publiques? Revue Française d'Économie 23(2) Nannestad, Peter. 2004. Immigration as a challenge to the Danish welfare state? European Journal of Political Economy 20: 755-767.

Nannestad, Peter. 2007. Immigration and Welfare States: A Survey of 15 Years of Research. European Journal of Political Economy 23(2): 512-532.

Napierała, Joanna and Agata Górny. 2011. Badania migrantów jako przedstawicieli populacji "ukrytych" - dobór próby sterowany przez respondentów (Respondent Driven Sampling). In: Kaczmarczyk P. (ed.). Mobilność i migracje w dobie transformacji, wyzwania metodologiczne. Warsaw: Wydawnictwo Naukowe Scholar. pp.155194.

OECD. 2012a. Education at aGlance. OECD Indicators. Paris: OECD.

OECD. 2012b. Health at a Glance. Paris: OECD.

OECD. 2013. The fiscal impact of immigration in OECD countries. In: OECD. International Migration Outlook. Paris: OECD.

Okólski, Marek. 2012. Transition from emigration to immigration: Is it the destiny of modern European countries? In: Okólski M. (ed.). European Immigrations: Trends, Structures and Policy Implications. Amsterdam: Amsterdam University Press. pp.23-44.

Paniagua, Toni A. 2009. Burden or resource? The Positive Impact of Immigration on the Italian Welfare State. University of North Carolina, Chapel Hill (mimeo).

Passel, Jeffrey and Rebecca L. Clark. 1994. How Much Do Immigrants Really Cost? A Reappraisal of Huddle's "The Costs of Immigrants". Washington D.C.: Urban Institute.

Pellizzari, Michele. 2011. The Use of Welfare by Migrants in Italy. IZA Discussion Papers No. 5613, Institute for the Study of Labor (IZA).

Piore, Michael. 1980. Birds of Passage: Migrant Labor and Industrial Societies. Cambridge: Cambrdige University Press.

Riphahn, Regina T. 2004. Immigrant Participation in Social Assistance Programs: Evidence from German Guestworkers. Applied Economics Quaterly 50(4): 329-362.

Riphahn, Regina, Sander, Monika and Christoph Wunder. 2010. The Welfare Use of Immigrants and Natives in Germany: The Case of Turkish Immigrants. LASER Discussion Papers - Paper No. 44.

Roodenburg, Hans, Euwals, Rob and Harry ter Rele. 2003. Immigration and the Dutch Economy. The Hague: CPB Netherlands Bureau for Economic Policy Analysis.

Rowthorn, Robert. 2008. The fiscal impact of immigration on the advanced economies. Oxford Review of Economic Policy 24(3): 560-580.

Sciortino, Giuseppe. 2004. Immigration in a Mediterranean Welfare State: The Italian Experience in Comparative Perspective. Journal of Comparative Policy Analysis 6(2): 111 - 129.

Sedlak \& Sedlak. 2013. Wynagrodzenia w Warszawie w 2012 roku. Warsaw: Sedlak \& Sedlak.

Simon, Julian. 1984. Immigrants, Taxes and Welfare in the United States. Population and Development Review 10(1): 55-69.

Simon, Julian. 1989. The Economic Consequences of Immigration. Boston: Basil Blackwell. 
Sinn, Hans-Werner. 2002. EU Enlargement and the future of the welfare state. Scottish Journal of Political Economy 49(1): 104-115.

Smith, James and Barry Edmonston (Eds). 1997. The New Americans: Economic, Demographic, and Fiscal Effects of Immigration. Washington: National Research Council.

Sriskandarajah, Dhananjayan, Cooley, Laurence and Howard Reed. 2005. Paying their way. The fiscal contribution of immigrants in the UK. London: IPPR.

Storesletten, Kjetil. 2000. Sustaining Fiscal Policy through Immigration. Journal of Political Economy 108(2): 300-323.

Storesletten, Kjetil. 2002. Fiscal Implications of Immigration - A Net Present Value Calculation. IIES Seminar Papers 701. Stockholm: IIES.

Thompson, Steven, and George Seber. 1996. Adaptive Sampling. New York: Wiley.

Turk, Philip, and John Borkowski. 2005. "A Review of Adaptive Cluster Sampling 1990-2003." Environmental and Ecological Statistics 12: 55-94.

Wadensjö, Eskil and Helena Orrje. 2002. Immigration and the Public Sector in Denmark. Aarhus: Aarhus University Press.

Wadensjö, Eskil. 2007. Immigration and net transfers within the public sector in Denmark. European Journal of Political Economy 23(2): 472-485.

Wellisch, Dietmar and Uwe Waltz. 1998. Why do rich countries prefer free trade over free migration? The role of the modern state, European Economic Review 42: 1595-1612.

Wellish, Dietman and David E. Wildasin. 1996. Decentralized income redistribution and immigration, European Economic Review 40: 187-217.

Wildasin, David E. 1994. Income Redistribution and Migration, Canadian Journal of Economics 27(3): 637-656.

Wong, Kar-Yui. 1985. The economic analysis of international migration: a generalization, Canadian Journal of Economics 19: 356-62.

Wong, Kar-Yui. 1995. International Trade in Goods and Factor Mobility. Cambridge: Cambridge University Press. 
Table 1a. Fiscal impacts of immigration - outcomes of selected empirical studies

\begin{tabular}{|c|c|c|}
\hline Author(s) & Country & Summary of main outcomes \\
\hline Simon 1984 & US & $\begin{array}{l}\text { Positive fiscal impacts of immigration; Tax contribution of immigrants can be higher than of } \\
\text { natives }\end{array}$ \\
\hline Akbari 1989 & Canada & $\begin{array}{l}\text { Positive fiscal impacts of immigration; Immigrants who resided in Canada up to } 35 \text { are } \\
\text { assessed as net contributors }\end{array}$ \\
\hline Borjas and Trejo 1991 & US & $\begin{array}{l}\text { Higher shares of welfare participation in the case of immigrants; Increase in welfare } \\
\text { consumption of immigrants attributed to change in ethnic mix }\end{array}$ \\
\hline Borjas and Trejo 1993 & US & $\begin{array}{l}\text { Higher shares of welfare participation in the case of immigrants; Structural characteristics of } \\
\text { immigrants explain } 2 / 3 \text { of the variance of welfare use rate }\end{array}$ \\
\hline Huddle 1993 & US & $\begin{array}{l}\text { Net fiscal impact of immigration: }-0.4 \text { percent of GDP; flat rate of taxation and displacement } \\
\text { effect assumed }\end{array}$ \\
\hline Borjas 1994 & US & Net fiscal impact of immigration: -0.2 percent of GDP \\
\hline Passel and Clark 1994 & US & Fiscal impacts of immigration: 0.4 percent of GDP \\
\hline Borjas and Hilton 1996 & US & $\begin{array}{l}\text { Overrepresentation of immigrants among welfare users; network effect confirmed; generally, } \\
\text { negative impact on the fiscal situation }\end{array}$ \\
\hline Lee and Miller 1998 & US & Positive impact: 0.35 percent of GDP; costs of public goods not considered \\
\hline Lee and Miller 2000 & US & $\begin{array}{l}\text { Positive impact; Effect of increase the number of immigrants by } 100 \text { thousand annually: } 0.4 \\
\text { percent of tax revenue }\end{array}$ \\
\hline Brücker et al. 2002 & EU & $\begin{array}{l}\text { Positive impact; Immigrants generate relatively large but transitory contribution to the } \\
\text { pension system; Differences between countries noted }\end{array}$ \\
\hline Boeri 2010 & EU & $\begin{array}{l}\text { No unequivocal outcome; No residual welfare dependency when controlling for observables; } \\
\text { Selective immigration policy recommended }\end{array}$ \\
\hline Barrett and Maitre 2011 & EU & Mixed results; Significant changes between Scandinavian countries and the rest of the EU \\
\hline OECD 2013 & OECD & $\begin{array}{l}\text { Mixed results for OECD countries; generally net fiscal position is small in terms of GDP with } \\
\text { labor market status as the single most important explanatory variable }\end{array}$ \\
\hline Bird et al. 1999 & Germany & $\begin{array}{l}\text { Negative impact; Immigrants more often rely on welfare (than natives); welfare usage to be } \\
\text { explain by their structural characteristics and not immigrant status itself }\end{array}$ \\
\hline Castronova et al. 2001 & Germany & $\begin{array}{l}\text { Negative impact; Immigrants more often rely on welfare (than natives); welfare usage to be } \\
\text { explain by their structural characteristics and not immigrant status itself }\end{array}$ \\
\hline Sinn 2000 & Germany & Negative impact; Post-accession migration presented as a threat to EU welfare systems \\
\hline Riphan 2004 & Germany & Negative impact; Strong assimilation effects confirmed \\
\hline Büchel and Frick 2004 & Germany/UK & $\begin{array}{l}\text { Strong dependency on welfare in case of Germany; much less in the UK - negative effects for } \\
\text { Germany, positive for the UK }\end{array}$ \\
\hline Riphahn et al. 2010 & Germany & $\begin{array}{l}\text { Negative impact; High welfare dependence found for Turkish immigrants; They disappear } \\
\text { though while controlling for structural characteristics }\end{array}$ \\
\hline $\begin{array}{l}\text { Weber and Straubhaar } \\
1999\end{array}$ & Switzerland & Positive impact; 0.2 percent of GDP \\
\hline Gott and Johsnton 2002 & UK & Positive impact; 0.27 percent of GDP \\
\hline $\begin{array}{l}\text { Sriskandarajah et al. } \\
2005\end{array}$ & UK & $\begin{array}{l}\text { Net fiscal position of immigrants is positive, higher for newcomers and stable even in time of } \\
\text { budget deficit }\end{array}$ \\
\hline Rowthorn 2008 & UK & 0.6 billion GBP (small but positive), differences between skill levels assumed \\
\hline Dustmann et al. 2010 & UK & Fiscal position of A8 immigrants assessed as very positive as compared to natives \\
\hline $\begin{array}{l}\text { Barrett and McCarthy } \\
2008\end{array}$ & Ireland & Positive impact; Immigrants found to be less likely than natives in welfare receipt \\
\hline Wadensjö 1999 & Denmark & $\begin{array}{l}\text { Mixed results; Net fiscal contribution assessed as positive in case of immigrants from Western } \\
\text { countries, negative for those coming from less developed ones }\end{array}$ \\
\hline Nannestad 2004 & Denmark & Negative impact; Immigrants from non-Western countries found to be net beneficiaries \\
\hline Blume and Werner 2007 & Denmark & Negative impact; Significant relationship between welfare dependence and country of origin \\
\hline Wadensjö 2007 & Denmark & $\begin{array}{l}\text { Positive impact; Effects much smaller (but positive) for non-Western migrants, differences } \\
\text { between levels of government }\end{array}$ \\
\hline Ekberg 1999 & Sweden & $\begin{array}{l}\text { Mixed results: positive contribution in 1950s-1970s, negative later on (attributable to worse } \\
\text { situation of immigrants on the labor market }\end{array}$ \\
\hline $\begin{array}{l}\text { Hansen and Lofstrom } \\
2003\end{array}$ & Sweden & $\begin{array}{l}\text { Negative impact; It is possible for immigrants to assimilate out of the welfare but it is a long } \\
\text { process }\end{array}$ \\
\hline Andren 2007 & Sweden & Negative impact; Strong dependence on welfare shown (in case of immigrants) \\
\hline $\begin{array}{l}\text { Hansen and Lofstrom } \\
2009\end{array}$ & Sweden & $\begin{array}{l}\text { Much higher welfare dependency in case of immigrants; significant differences between } \\
\text { particular groups (with refugees being "trapped" in welfare dependency) }\end{array}$ \\
\hline
\end{tabular}




\begin{tabular}{|c|c|c|}
\hline Andren and Andren 2012 & Sweden & Negative impact; Strong dependence on welfare shown (in case of immigrants) \\
\hline Sciortino 2004 & Italy & $\begin{array}{l}\text { Negative impact; Interactions between welfare system and other systems (labor market) do } \\
\text { matter }\end{array}$ \\
\hline Paniagua 2009 & Italy & Positive impact; Importance of various modes of labor market participation stressed \\
\hline Pellizzari 2011 & Italy & $\begin{array}{l}\text { Negative impact; Higher welfare dependency among non-European immigrants observed (but } \\
\text { not when controlled for observable characteristics) }\end{array}$ \\
\hline $\begin{array}{l}\text { Auerbach and } \\
\text { Oreopoulos } 1999\end{array}$ & US & $\begin{array}{l}\text { Mixed results; Massive change in immigration policy (halting all migration) has only small } \\
\text { effect on the US treasury }\end{array}$ \\
\hline Storesletten 2000 & US & $\begin{array}{l}\text { Positive impact; Targeted immigration policy as partial solution of budgetary problems; All } \\
\text { efficient naturalization actions are expected to improve fiscal position of the US }\end{array}$ \\
\hline $\begin{array}{l}\text { Smith and Edmonston } \\
1997\end{array}$ & US & $\begin{array}{l}\text { Positive impact; Immigrants and their descendants create net fiscal gains, they are very high } \\
\text { for highly skilled ones; Outcomes are very sensitive to the income position of immigrants }\end{array}$ \\
\hline Bonin 2002 & Germany & $\begin{array}{l}\text { Positive outcomes due to favorable age structure of immigrants (in } 1996 \text { used as base year); } \\
\text { even better outcomes expected in case of targeted immigration policy }\end{array}$ \\
\hline Bonin 2006 & Germany & Positive net effects both in terms of static as well as dynamic assessment \\
\hline Chojnicki and Ragot 2011 & France & $\begin{array}{l}\text { Positive impact; Selective immigration policies were expected to reduce the tax burden } \\
\text { resulting from ageing by } 50 \text { percent by } 2050\end{array}$ \\
\hline Monso 2008 & France & $\begin{array}{l}\text { Impact difficult to assess but small or negligible (short term positive impacts are offset by long } \\
\text { term costs) }\end{array}$ \\
\hline Rodenburg et al. 2003 & Netherlands & $\begin{array}{l}\text { Fiscal impact of immigration depends on structural characteristics, it is negative for non- } \\
\text { Western immigrants }\end{array}$ \\
\hline Storesletten 2002 & Sweden & $\begin{array}{l}\text { Negative impact; But: outcomes very sensitive to assumptions and age structure of } \\
\text { newcomers; if the } 1990 \text { age structure is applied significant losses are expected }\end{array}$ \\
\hline Collado et al. 2004 & Spain & Positive impact; Immigration as a significant factor improving fiscal position of Spain \\
\hline
\end{tabular}

Source: Own elaboration 
Table 2a. Social benefits in Poland and Mazowieckie region, 2012, in PLN

\begin{tabular}{|c|c|c|c|}
\hline Type of benefit & Total expenditure & Persons entitled & Average per person \\
\hline \multicolumn{4}{|c|}{ POLAND } \\
\hline Benefits total & 3053421689 & 1917817 & 1592.13402 \\
\hline Permanent benefits & 711453414 & 197767 & 3597.432403 \\
\hline Temporary benefits & 727349990 & 479937 & 1515.51139 \\
\hline \multicolumn{4}{|l|}{ including: } \\
\hline Unemployment related benefits & 611311527 & 387746 & 1576.577262 \\
\hline Illness related benefits & 34181113 & 39833 & 858.1104361 \\
\hline Disability related benefits & 37327087 & 47213 & 790.6103616 \\
\hline Housing & 40410675 & 15648 & 2582.481787 \\
\hline Food & 455725395 & 831805 & 547.8752773 \\
\hline Purpose benefits & 10994677 & 5547 & 1982.094285 \\
\hline Care services (total) & 360639831 & 85545 & 4215.790882 \\
\hline \multicolumn{4}{|c|}{ MAZOWIECKIE } \\
\hline Beneftis total & 334580207 & 217098 & 1541.148269 \\
\hline Permanent benefits & 99161585 & 26400 & 3756.120644 \\
\hline Temporary benefits & 45545384 & 34159 & 1333.334817 \\
\hline \multicolumn{4}{|l|}{ including: } \\
\hline Unemployment related benefits & 36859865 & 26874 & 1371.580896 \\
\hline Illness related benefits & 3083420 & 3815 & 808.2359109 \\
\hline Disability related benefits & 2640036 & 3111 & 848.6133076 \\
\hline Housing & 1883430 & 775 & 2430.232258 \\
\hline Food & 56917274 & 99510 & 571.9754196 \\
\hline Purpose benefits & 1498568 & 659 & 2274.003035 \\
\hline Care services (total) & 44019936 & 12203 & 3607.304433 \\
\hline
\end{tabular}

Source: Own elaboration based on the Ministry of Labour data 